\title{
THE FUNCTIONAL METHOD OF COMPARATIVE LAW
}

\author{
RALF MICHAELS \\ Durham, North Carolina*
}

I. 'The Functional Method'

II. Concepts of Functionalism 343
1. Finalism
345
2. Adaptionism
347
3. Classical Functionalism
349
4. Instrumentalism
351
5. Refined Functionalism
352
6. Epistemological Functionalism
7. Equivalence Functionalism
356
8. Functionalist Comparative Law: Synthesis or Eclecticism? 360

III. Functions of Function

1. The Epistemological Function: Understanding Law 364

2. The Comparative Function: Tertium Comparationis $\quad 367$

3. The Presumptive Function: Praesumptio Similitudinis $\quad 369$

4. The Systematizing Function: Building a System 372

5. The Evaluative Function: Determining the Better Law 373

* This essay was finalized while I was a Lloyd Cutler Fellow at the American Academy in Berlin. Special thanks for comments to Donald Horowitz, Joan Magat, and the editors. 
6. The Universalizing Function: Unifying Law

\section{I. 'The Functional Method'}

THE functional method has become both the mantra and the bette noire of comparative law. For its proponents it is the most, perhaps the only, fruitful method; ${ }^{1}$ to its opponents it represents everything bad about mainstream comparative law. The debate over the functional method is indeed much more than a methodological dispute. It is the focal point of almost all discussions about the field of comparative law as a whole-centres versus peripheries of scholarly projects and interests, mainstream versus avant-garde, convergence versus pluralism, instrumentalism versus hermeneutics, technocracy versus culture, and so on.

This functional method is a chimera, in both theory and practice of comparative law. As theory it hardly exists, at least in an elaborated version. The standard reference text for supporters and opponents alike is a brief chapter in an introductory textbook, a text that in its original conception is almost half a century of age ${ }^{2}$ and whose author, Zweigert, expressed both disdain for methodological debate ${ }^{3}$

\footnotetext{
1 See, eg, for the United States, John Reitz, 'How to do Comparative Law', (1998) 46 AJCL 617, 620-3; Mathias Reimann, 'The Progress and Failure of Comparative Law in the Second Half of the Twentieth Century', (2003) 50 AJCL 671, 679 f; for France, Marc Ancel, Utilité et méthodes de droit comparé (1971), 97 f, 101-3; idem, 'Le problème de la comparabilité et la méthode fonctionnelle en droit comparé', in Festschrift für Imre Zajtay (1982), 1-6; for England, Hugh Collins, 'Methods and Aims of Comparative Contract Law', (1989) 11 Oxford Journal of Legal Studies 396-406; Peter de Cruz, Comparative Law in a Changing World (2nd edn, 1999), 230 ff; for Germany, Hein Kötz, 'Comparative Law in Germany Today', (1999) 51 RIDC 753, 755 f; for Scandinavia, Michael Bogdan, Comparative Law (1994), 59-60; for a socialist perspective, Imre Szabó, 'Theoretical Questions of Comparative Law', in Imre Szabó and Zoltán Péteri (eds), A Socialist Approach to Comparative Law (1977), 9, 36-8; for rise and fall in Italy, Pier Giuseppe Monateri, 'Critique et différence: Le droit comparé en Italie', (1999) 51 RIDC 989, $991 \mathrm{f}$.

2 Konrad Zweigert and Hein Kötz, An Introduction to Comparative Law (trans Tony Weir, 3rd edn, 1998), 32-47, first published in Einführung in die Rechtsvergleichung (vol I, 1971), 27-48; Konrad Zweigert, 'Methodological Problems in Comparative Law', (1972) 7 Israel LR 465-74. Earlier versions are Konrad Zweigert, 'Méthodologie du droit comparé', in Mélanges offerts à Jacques Maury (vol I, 1960), 579-96 = 'Zur Methode der Rechtsvergleichung', (1960) 13 Studium Generale-Zeitschrift für die Einheit der Wissenschaften im Zusammenhang ihrer Begriffsbildung und Forschungsmethoden 193-200; Ernst von Caemmerer and Konrad Zweigert, 'Évolution et état actuel de la méthode du droit comparé en allemagne', in Livre du Centenaire de la société de législation comparée (1969), 267, 282-97. The functional approach to comparative law had been practised in Germany and elsewhere earlier; see Max Rheinstein, 'Comparative Law and Conflict of Laws in Germany', (1934-5) 2 University of Chicago
} 
and a preference for inspiration over methodological rigour as the comparatist's ultimate guide. ${ }^{4}$ Even a seminal text like Zweigert's cannot possibly provide all elements of a theory, nor suffice to refute all criticism directed against it. Moreover, even a spurious overview of comparative law theory reveals that functionalism is, and has always been, only one of several approaches towards micro-comparison. At least three main current approaches other than functionalism remain: ${ }^{5}$ comparative legal history, the study of legal transplants, and the comparative study of legal cultures.

Concerning practice, the functional approach underlies some famous successful and methodologically explicit studies, but they are famous in no small part because they are so rare. ${ }^{6}$ More often, for supporters and opponents alike, 'functional method' merely serves as shorthand for traditional comparative law. Two recent works on similar topics illustrate this. Stefan Vogenauer explicitly places his comprehensive comparative study of statutory interpretation within the functional tradition, ${ }^{7}$ although his analysis focuses on forms of legal argument rather than functions. In contrast, Mitchel Lasser describes the method behind his comparison of judicial styles as a (cultural) analysis of mentalités, ${ }^{8}$ but then he explains different

LR 232, 250; Hans G. Ficker, 'L'état du droit comparé en Allemagne', (1958) 10 RIDC 701, 716-18; M. Schmitthoff, 'The Science of Comparative Law', (1939-41) 7 Cambridge LJ 94, 96 ff; Tullio Ascarelli, Studi di diritto comparato e in tema di interpretazione (1952), $1 \mathrm{ff}$.

3 Below, n 109.

4 See Zweigert and Kötz (n 2), 33, expressing approval of a statement by Gustav Radbruch, Einführung in die Rechtswissenschaft (9th edn, 1958), 242 ('Wissenschaften, die sich mit ihrer eigenen Methodenlehre zu beschäftigen Anlaß haben, sind kranke Wissenschaften'; '. . . sciences which have to busy themselves with their own methodology are sick sciences'); but cf the more distanced attitude in Zweigert, 'Zur Methode' (n 2), 193 ('mag auf sich beruhen'). See already Franz von Liszt, 'Das “richtige Recht” in der Strafgesetzgebung', in Konrad Zweigert and Hans-Jürgen Puttfarken (eds), Rechtsvergleichung (1978), 57, 58; originally in (1906) 26 Zeitschrift für die gesamte Strafrechtswissenschaft 553-7: 'Es pflegen nicht eben die schaffenskräftigsten unter den Gelehrten zu sein, die sich der Erörterung methodologischer Fragen zuwenden' (Usually, the scholars who deal with issues of methodology are not the most productive ones).

5 cf the lists in Béatrice Jaluzot, 'Méthodologie du droit comparé: Bilan et prospective', (2005) 57 RIDC 29, 38 ff; Alessandro Somma, 'Al capezzale del malato? Riflessioni sul metodo comparatistico', (2005) 23 Rivista critica del diritto privato 401-47; also in idem, Tecniche e valori nella ricerca comparatistica (2005), 3-71.

6 Michele Graziadei, 'The Functional Heritage', in Pierre Legrand and Roderick Munday (eds), Comparative Legal Studies: Traditions and Transitions (2003), 100, 100 f.; Vernon Valentine Palmer, 'From Lerotholi to Lando: Some Examples of Comparative Law Methodology', (2005) 53 AJCL 261, 285. Annelise Riles, 'Wigmore's Treasure Box: Comparative Law in the Era of Information', (1999) 40 Harvard International LJ 221, 236 f calls functionalism a 'compromised methodology'.

7 Stefan Vogenauer, Die Auslegung von Gesetzen in England und auf dem Kontinent (vol I, 2001), 18 n 105; see now also idem, 'Eine gemeineuropäische Methodenlehre des Rechts: Plädoyer und Programm', (2005) 13 Zeitschrift für Europäisches Privatrecht 234, 246-9.

8 Mitchel de S.-O.-l'E. Lasser, Judicial Deliberations (2004), 362; cf idem, 'The Question of Understanding', in Legrand and Munday (n 6), 197-239. 
styles of legal systems as equivalent regarding the functions they serve: transparency, judicial accountability, and control. ${ }^{9}$

In short, 'the functional method' is a triple misnomer. First, there is not one ('the') functional method, but many. Second, not all allegedly functional methods are 'functional' at all. Third, some projects claiming adherence to it do not even follow any recognizable 'method'. Does functionalist comparative law actually have any meaning? Functionalist comparatists agree on some important elements. First, functionalist comparative law is factual, it focuses not on rules but on their effects, not on doctrinal structures and arguments, but on events. As a consequence, its objects are often judicial decisions as responses to real life situations, and legal systems are compared by considering their various judicial responses to similar situations. Second, functionalist comparative law combines its factual approach with the theory that its objects must be understood in the light of their functional relation to society. Law and society are thus thought to be separable but related. Consequently, and third, function itself serves as tertium comparationis. Institutions, both legal and non-legal, even doctrinally different ones, are comparable if they are functionally equivalent, if they fulfil similar functions in different legal systems. A fourth element, not shared by all variants of functional method, is that functionality can serve as an evaluative criterion. Functionalist comparative law then becomes a 'better-law comparison'-the better of several laws is that which fulfils its function better than the others.

This chapter tries to reconstruct and evaluate functionalist comparative law by placing it within the larger framework of other disciplines, especially the social sciences. It is of course a risk for a comparative lawyer to use disciplines foreign to his own—sociology, anthropology, philosophy—as lenses on his own discipline. But comparatists know that looking through the eyes of foreign law enables us better to understand our own, so looking through the eyes of foreign disciplines should similarly help us better to understand our own discipline. Such an interdisciplinary analysis yields three promises. First, the interdisciplinary look should enable a (re-)construction of a more theoretically grounded functional method of comparative law than is usually presented (Section II). This should reveal its connections with and its peculiarities within both the development of comparative law and the development of functionalism in other disciplines. Second, the interdisciplinary approach should help formulate and evaluate the concept in order to determine how functional the method really is (Section III). Just as comparative law can borrow from the development of functional methods in the social sciences, so it can borrow from the development of critique. However, comparative law is not a social science, and herein lies the third promise of an interdisciplinary

\footnotetext{
9 Lasser, Judicial Deliberations (n 8), 299 ff; see also idem, 'Is there a Transatlantic Common Core of Judicial Discourse?', in Mauro Bassani and Ugo Mattei (eds), The Common Core of European Private Law (2003) 213-9.
} 
approach: The comparison with functionalism in other disciplines may reveal what is special about functionalism in comparative law, and why what in other disciplines would rightly be regarded as methodological shortcomings may in fact be fruitful for comparative law.

\section{Concepts of Functionalism}

In 1971, Konrad Zweigert postulated a methodological monopoly: 'The basic methodological principle of all comparative law is that of functionality.' ${ }^{10}$ Twelve years before him, Kingsley David had done something similar for sociology and social anthropology when he had called structural-functional analysis, 'in effect, synonymous with sociological analysis'. ${ }^{11}$ Similarly again, Laura Kalman remarked that the statement that we are all (legal) realists now 'has been made so frequently that it has become a truism to refer to it as a truism'. ${ }^{12}$

Such claims of monopoly suggest a lack of conceptual clarity, or a lack of theoretical sophistication, or both. If functionalism is the only method in a discipline, chances are that either the discipline does not recognize all of its potential, or the notion of functional method is itself inflated into a meaninglessly broad concept. Indeed, neither Davis nor Kalman thought a specified version of functionalism had won the day in their respective disciplines. Davis proposed to drop the notion of functionalism because it blurred the underlying methodological differences. ${ }^{13}$ Similarly, the 'we are all realists now' quote has been used as a strategy to conceal the special contributions of legal realism ${ }^{14}$ rather than to adopt their general ones, a way of beating realism by embracing it to death. If we are all functionalists of comparative law, as Zweigert proclaims, then functionalism cannot mean very much. (Nor, as one tends to overlook, can its rejection by its critics.)

The reconstruction of a more precise concept of functionalism in each discipline

10 Zweigert and Kötz (n 2), 34 .

11 Kingsley Davis, 'The Myth of Functional Analysis as a Special Method in Sociology and Anthropology', (1959) 24 American Sociological Review 757, 757.

12 Laura Kalman, Legal Realism at Yale, 1927-1960 (1986), 229. See also Lawrence Rosen, 'Beyond Compare', in Legrand and Munday (n 6), 493, 504, ending his critique of functionalism by proclaiming: 'In some sense, of course, we are all functionalists and that is all to the good inasmuch as it leads us to see connections we might not otherwise have thought obtained'.

13 For example Radcliffe-Brown called himself an anti-functionalist just in order to distinguish himself from the other great functionalist, Malinowski: Alfred R. Radcliffe-Brown, 'Functionalism: A Protest', (1949) 51 American Anthropologist 320, 321.

14 See, most recently, Hanoch Dagan, 'The Realist Conception of Law', (2005) Tel Aviv University Law Faculty Papers 21. 
reveals another, less obvious but more important, problem-functionalism means different things in different disciplines. Superficially, one would expect to find similarities. After all, the turn in the nineteenth and twentieth centuries away from essentialist to functionalist methods, from observation of objects themselves to observation of their relations amongst each other and to the whole, was so widespread that one could speak of a general 'functionalist turn' away from essentialism in all academic disciplines and beyond, for example, in architecture and design ('form follows function'). There may indeed have been no more fashionable concept in the twentieth century than that of function. ${ }^{15}$ This simultaneous rise and fall of functionalism in different disciplines suggests a parallel, perhaps even a common development, or evolution, of ideas. ${ }^{16}$ Similarity becomes even more plausible in view of cross-fertilizations between disciplines: ${ }^{17}$ Ernst Cassirer transposed the notion from mathematics and science to philosophy; ${ }^{18}$ sociologists from Comte and Spencer via Durkheim to Parsons and Luhmann borrowed biological concepts; lawyers like Jhering and Pound were inspired by sociological ideas of function.

But such cross-fertilization, as comparatists know well from the legal transplants debate, is not immune to misunderstandings and alterations, known or unknown. The story of a common development, alluring as it may be, tends to overlook the differences between concepts and disciplines and, as a consequence, the differences between different kinds of functionalism. This is especially problematic for a discipline like comparative law that sees its place somewhere between the social sciences on the one hand and legal studies on the other, and that draws methodological inspiration from both. If the concepts and methods in these disciplines are different, the result can only be methodological mishmash.

In fact, one can distinguish at least seven different concepts of functionalism across disciplines: ${ }^{19}$ (1) finalism, a neo-Aristotelian functionalism based on inherent teleology, (2) adaptionism, an evolutionary functionalism in a Darwinian tradition, (3) classical (Durkheimian) functionalism, explaining institutions through their usefulness for society, (4) instrumentalism, a normative theory of using law for social engineering, (5) refined functionalism, a functionalist method that replaces certain postulates of classical functionalism with empirically testable hypotheses,

15 Reiner Wiehl, Subjektivität und System (2000), 375.

16 Connections are drawn eg by Rudolf B. Schlesinger, Hans W. Baade, Peter E. Herzog, and Edward M. Wise, Comparative Law (6th edn, 1998), 49; Rosen (n 12), 504.

17 For examples from writers in two different disciplines, see the references in Robert K. Merton, 'Manifest and Latent Functions', in idem, Social Theory and Social Structure (1968), 73, 101 n 50; reprinted eg in N. J. Demerath III and Richard A. Peterson (eds), System, Change, and Conflict: A Reader on Contemporary Sociological Theory and the Debate over Functionalism (1967), 10; Felix S. Cohen, 'Transcendental Nonsense and the Functional Method', (1935) 35 Columbia LR 809, 824-9; idem, 'The Problems of a Functional Jurisprudence', (1937), Modern LR 5, 9.

18 Ernst Cassirer, Substanzbegriff und Funktionsbegriff (1910).

19 For another classification of different concepts of functionalism, see Martin Mahner and Mario Bunge, 'Function and Functionalism: A Synthetic Perspective', (2001) 68 Philosophy of Science 75-94. 
(6) epistemological functionalism, an epistemology that focuses on functional relations rather than on the ontology of things, and (7) equivalence functionalism, building on these concepts but emphasizing the non-teleological, non-causal aspect of functional relations. Largely oblivious of incompatibilities, functionalist comparative law (8) uses all of these.

\section{Finalism}

Functionalist comparative law shares its emphasis on generalities that transcend national boundaries with the Natural law tradition, and indeed finds one of its origins there. Kant, while positing a strict separation between 'is' and 'ought,' had conceived the possibility of universal law based on reason. Neo-Kantians hoped to use comparative law as a response to Kirchmann's famous verdict on law as nonscientific and as a way towards a rational law. In 1905, Gustav Radbruch proposed a Kantian version of ideal law as tertium comparationis for solutions to similar problems. This ideal law could not be deduced from the insights of comparative law (that would have been an is/ought crossover), but its formulation could help psychologically in the quest for better law. ${ }^{20}$ Twenty years later, Max Salomon expanded on these thoughts and formulated the credo of modern functionalist comparative law: Legal science, like every science, deals with universals, but these universals are not legal norms but rather legal problems. As a consequence, a comparison of legal norms is possible only of norms responding to the same legal problems. ${ }^{21}$ Legal science is possible only as comparative law.

Another source lies in Aristotle's philosophy, where the idea that law performs some function for society in an unspecific sense can already be found. For Aristotle, the purpose of things, their telos or causa finalis, belonged to their nature.

20 Gustav Radbruch, 'Über die Methode der Rechtsvergleichung', (1905-6) 2 Monatsschrift für Kriminalpsychologie und Strafrechtsreform 422-5; reprinted in Zweigert and Puttfarken (n 4), 52-6 and in Heinrich Scholler (ed), Gustav Radbruch-Rechtsvergleichende Schriften (Gustav Radbruch Gesamtausgabe, vol 15, 1999), 152-6. See also idem, Rechtsphilosophie (1932), 120 (Wertbeziehung [value relation] as scientific criterion for legal science). For a stricter application of the is/ought argument and critical response to both Radbruch and Salomon, see Julius Binder, Philosophie des Rechts (1925), $951 \mathrm{ff}$; for the possibility of a Natural law derived from the comparison of positive laws, see von Liszt (n 4), 61 f; Konrad Zweigert, 'Rechtsvergleichung als universale Interpretationsmethode', (1949) 15 Rabels $Z_{5}, 19-20$.

21 Max Salomon, Grundlegung zur Rechtsphilosophie (1925), 34 ('Rechtswissenschaft ist nicht eine Wissenschaft von den Rechtsnormen, sondern von den Rechtsproblemen'; legal science is a science not of legal norms but of legal problems), 33 ('Rechtsvergleichung ist Vergleichung von Lösungen eines einheitlichen Problems'; comparative law is the comparison of solutions to a uniform problem); for approval, see Radbruch, Rechtsphilosophie (n 20), 120 n 19; Schmitthoff (n 2), 96; Willis Santiago Guerra Filho, 'A dimensão processual dos direitos fundamentais e da Constituição', (1998) 137 Revista de Informação Legislativa 13, 20-1; cf Otto Sandrock, Über Sinn und Methode zivilistischer Rechtsvergleichung (1966), $16 \mathrm{f}$. 
Underlying this was a teleological image of the world, in which everything strove towards perfection. 'Is' and 'ought' were connected: the correct laws could be deduced from the nature of things. Such thoughts were later rejected both in philosophy and in legal theory, before the crisis of legal positivism spurred a simultaneous return to Natural law and comparative law, and to Aristotelian ideals, in the twentieth century. Once it could be shown that not only problems but also their solutions were similar, a return to a minimal version of Natural law or at least ius gentium, based on an Aristotelian notion of function, seemed possible. To this end, the revived rhetorical tradition of topics could be made fruitful. ${ }^{22}$ Topics, taking the role of problems, did not spur universal solutions by themselves, but inspired similar analyses that might lead to similar results. Comparative law became phenomenological:23 Comparatists viewed the solutions in different legal systems as responses to common problems, contingent in their form but none the less required by the nature of the problem.

The most important theoretical treatise in this tradition and, at the same time, one of the most important works for functionalist comparative law is Josef Esser's book on principles and rules in judicial lawmaking. ${ }^{24}$ Esser's functionalism is richer and more sophisticated than the one developed later by Zweigert, but its central elements are strikingly similar: Institutions are contingent while problems are universal, the function can serve as tertium comparationis, different legal systems find similar solutions by different means, so universal principles of law can be found and formulated as a system with its own terminology. ${ }^{25}$ The reason for the similarity is that solutions are deemed inherent in problems and arguments can be made from the Natur der Sache (the thing's nature); a commonality of values is both the basis for and the consequence of this. Another comparatist, more openly in the tradition of Aristotle and Thomas Aquinas, is James Gordley. ${ }^{26}$ His general approach is more philosophical than Esser's, but in effect quite similar: Gordley

22 Fritz von Hippel, Zur Gesetzmäßigkeit juristischer Systembildung (1931); Theodor Viehweg, Topik und Jurisprudenz (1954, 5th edn, 1974; English translation under the title Topics and Law by W. Cole Durham, 1993); Ernst A. Kramer, 'Topik und Rechtsvergleichung', (1969) 33 RabelsZ 1-16; for the history of legal topics, see also Jan Schröder, Recht als Wissenschaft (2001), 23-48 with references at 23 n 97.

23 Alois Troller, Überall gültige Prinzipien der Rechtswissenschaft (1965), especially at 4-5; idem, 'Rechtsvergleichung und Phänomenologie', in Mario Rotondi (ed), Inchieste di diritto comparato, vol II: Buts et méthodes du droit comparé (1973), 685-705, especially at 694; both with references to functionalist comparatists.

24 Josef Esser, Grundsatz und Norm in der richterlichen Rechtsfortbildung (1956), especially at $31 \mathrm{ff}$, $346 \mathrm{ff}$. Unfortunately no English translation exists; for reviews in English, see Max Rheinstein (to whom Esser dedicated his book), (1959) 24 University of Chicago LR 597-605; Wolfgang G. Friedmann, (1957) 57 Columbia LR 449-51; Arthur T. von Mehren, (1957) 22 RabelsZ 548-9. For an application of Esser's method by one of his students, see Dieter Rothoeft, System der Irrtumslehre als Methodenfrage der Rechtsvergleichung (1968).

25 Esser (n 24), ch 10.

26 James Gordley, 'The Universalist Heritage', in Legrand and Munday (n 6), 31-45; idem, The Foundations of Private Law: Property, Tort, Contract, Unjust Enrichment (2006), $1 \mathrm{ff}$. 
also sees different laws as different responses to the same, universal problems. ${ }^{27}$ Neo-Aristotelians postulate that comparative law can lead us to universal, common legal principles. Different laws provide answers to similar problems that are doctrinally (formally) different but substantively similar, and their relative similarity suggests inherently correct solutions to these problems-a Natural law, a ius commune (Gordley), a ius gentium (Esser), or 'universal legal principles' (Troller).

Both Esser and Gordley call their approaches functional, and both have been influential in functionalist comparative law. But they use function in a very specific sense: For them it is synonymous with purpose and causa finalis. This is quite different from the modern notion of function as developed by Durkheim. Durkheim explicitly distinguished an institution's functions from its cause and from its nature, rejected the Aristotelian fourfold concept of causa by confining 'cause' to causa efficiens, and replacing end or goal (causa finalis) with function. ${ }^{28}$ Since then, the function of a thing (or a law) is normally separated not only from the reasons for its origin and evolution, ${ }^{29}$ but also from its essence; functional relations are separate from the things themselves. Esser's and Gordley's functionalisms are different; they must be understood against the background of Aristotelian ontology and metaphysics and answer the criticisms brought forward against these.

\section{Adaptionism}

Darwinism discarded the Aristotelian worldview, but it did not simultaneously discard the teleological view of the world. ${ }^{30}$ The telos was now transferred into the world at large; the struggle of everyone against everyone was thought to contribute to the progress of the whole. Darwinian ideas influenced all disciplines in the nineteenth century, including the new discipline of sociology and the concept of function within it. Auguste Comte, who gave sociology its name, introduced a vision of society as a complex organism which evolved as a whole, while its elements all performed certain functions in this evolution. Herbert Spencer, closer to Darwinism, conceptualized society more as a struggle of all against all, but he also emphasized the important interplay between structures and their functions

27 See eg, James Gordley, 'Is Comparative Law a Distinct Discipline?', (1998) 46 AJCL 607-15.

28 Émile Durkheim, Les règles de la méthode sociologique (5th edn, 1988, originally published in 1894-5), 188: 'Nous nous servons du mot de fonction de préférence à celui de fin ou de but, précisément parce que les phénomènes sociaux n'existent généralement pas en vue des résultats utiles qu'ils produisent' (we use the word function rather than that of end or goal precisely because social phenomena do not generally exist in view of the useful results they produce).

29 Durkheim (n 28), 183: 'Faire voir à quoi un fait est utile n'est pas expliquer comment il est né ni comment il est ce qu'il est' (showing for what a fact is useful is not the same as explaining how it comes about nor why it is the way it is).

30 This is in dispute; for Darwin's own views of Aristotle (whom he discovered late in life), see Allan Gotthelf, 'Darwin on Aristotle', (1999) 32 Journal of the History of Biology 3-30. 
for society. ${ }^{31}$ Not surprisingly, evolutionist thought also influenced lawyers of the time, none more perhaps than Jhering, who argued that law developed in response to the needs not of individuals but of society. ${ }^{32}$ For all these scholars, institutions like the law respond, adapt to social needs; those institutions that adapt best will survive.

This version of functionalism, which one may call adaptionism, seemed especially apt for comparative law. ${ }^{33}$ That field had hitherto consisted largely of comparative legal history, understood as the history and diffusion of ideas and doctrines. The new sociological interest in interrelations between law and society changed this focus. Now ideas about law were drawn neither from texts nor from the spirit of a particular people, but from general ideas about societies and their development. Consequently, generalization across borders became possible; comparative law could become a science of the way in which societies dealt with similar problems on their paths toward progress. Central to this new approach was the focus on the functions that both law at large and its individual institutions fulfilled for society. An early example comes from Franz von Liszt, a supporter of a functional criminal law in the tradition of Beccaria (and a cousin to the famous composer). Liszt suggested that because punishment was necessary for maintenance of the legal order and because the legal order in turn was necessary for the maintenance and development of the state, criminal law norms had to be judged against their ability to maintain the legal order. ${ }^{34}$ This function was useful for comparative law; it served as the tertium comparationis for the (functional) comparison of criminal law in different legal orders. ${ }^{35}$ Philipp Heck, the most important proponent of a jurisprudence of interests, also argued for functionalist comparative law: Similarities of values among societies created laws different in doctrine but similar in results. ${ }^{36}$ Also, Roscoe Pound, while not a strict functionalist himself, shared

31 cf Jonathan H. Turner and Alexandra Maryanski, Functionalism (1979), 2-14; Richard Münch, 'Funktionalismus-Geschichte und Zukunftsperspektiven einer Theorietradition', in Jens Jetzkowitz and Carsten Stark (eds), Soziologischer Funktionalismus (2003), 17, 23-6.

32 Rudolf von Jhering, Der Zweck im Recht (1877-83; English translation under the title Law as a Means to an End by Isaac Husik, 1913); idem, Der Kampf ums Recht (1872; English translation under the title The Struggle for Law by John J. Lalor, 1979); on Jhering's concept of evolution see Okko Behrends (ed), Privatrecht heute und Jherings evolutionäres Rechtsdenken (1993); Marc Amstutz, Evolutorisches Wirtschaftsrecht (2002) 148-67.

33 Konrad Zweigert and Kurt Siehr, 'Jhering's Influence on the Development of Comparative Legal Method', (1971) 19 AJCL 215-31.

34 cf Franz von Liszt, Der Zweckgedanke im Strafrecht (1882-3). $\quad 35$ von Liszt (n 34), 60.

36 Philipp Heck, Begriffsbildung und Interessenjurisprudenz (1929), $133 \mathrm{f}$; idem, Grundriss des Schuldrechts (1929), 11: 'Die nationalen Rechte unterscheiden sich weniger in der Entscheidung der Interessenkonflikte als in den angewendeten Gebotsbegriffen und Gebotssystemen. Auch in dieser Hinsicht findet sich eine Aequivalenz der Konstruktionen und der Gebotssysteme. Die Verlegung des Schwergewichts auf die Interessenwirkung verringert den Gegensatz.' (National legal systems differ from each other less in how they decide between conflicting interests but rather in the norms and normative systems they apply. In this way, too, we find equivalence of constructions and systems. Moving the emphasis on interests reduces the difference.) Heck was inspired by a review of his 
some of functionalism's convictions. Pound was interested in 'law in action, not law in the books'37 and in 'how the same things may be brought about, the same problem may be met by one legal institution or doctrine or precept in one body of law and by another, quite different institution or doctrine or precept in another'38_ both central elements of functionalist comparative law.

Today, after the catastrophe of two world wars has rattled the faith both in teleological evolutionism and in progress through law, adaptionism survives in only a very reduced form. In political science it is used in some integration studies as an explanation of convergence, especially of the European Union. ${ }^{39}$ But the loss of teleology and awareness of the complexity of the world have made the simple functionalism of means and ends harder to justify both as an explanatory theory and as a guiding principle. Adaptionism seemed to suggest a false determinism. ${ }^{40}$ Evolutionary functionalism in political science has therefore been called ideological and ethnocentric, a criticism replicated in reference to comparative law. ${ }^{41}$

\section{Classical Functionalism}

Sociologists interested in a value-free sociological science perceived this as an illegitimate faith in progress and tried to develop a non-teleological functionalism instead. These efforts can be traced back to Émile Durkheim, who introduced two important ideas. First, he separated functions from origins and established functions as relations between, not qualities of, elements. Second, he emphasized that the goals of individuals were contingent and therefore not the valid material of scientific endeavours; sociology as a science had to focus on objective functions. ${ }^{42}$ Both steps had crucial implications. As long as the ends or goals of an institution

property book by Max Rheinstein, (1931) 60 Juristische Wochenschrift 2897, 2899: 'Die Rechtsvergleichung ist eine notwendige Ergänzung und Weiterführung der Interessenjurisprudenz' (comparative law is a necessary supplement and continuation of jurisprudence of interests). See also Heinrich Schoppmeyer, Juristische Methode als Lebensaufgabe (2001), $69 \mathrm{f}$ with $\mathrm{n} 154$.

37 Roscoe Pound, 'Law in the Books and Law in Action', (1910) 44 American LR 12-36; cf Karl H. Neumayer, 'Fremdes Recht aus Büchern, fremde Rechtswirklichkeit und die funktionelle Dimension in den Methoden der Rechtsvergleichung', (1970) 34 RabelsZ 411-25.

38 Roscoe Pound, 'What May We Expect from Comparative Law?, (1936) 22 ABAJ 56, 59.

39 David Mitrany, A Working Peace System: An Argument for the Functional Development of International Organization (1943); Ernst B. Haas, Beyond the Nation-State: Functionalism and International Organization (1964); David Long and Lucian M. Ashworth, 'Working for Peace: the Functional Approach, Functionalism and Beyond', in idem (eds), New Perspectives on International Functionalism (1999), 1-26; Jürg Martin Gabriel, 'Die Renaissance des Funktionalismus', (2000) 55 Aussenwirtschaft 121-68.

40 Robert W. Gordon, 'Critical Legal Histories', (1984) 36 Stanford LR 57-125; Günter Frankenberg, 'Critical Comparisons: Re-thinking Comparative Law', (1985) 26 Harvard International LJ 412, 438.

${ }^{41}$ Léontin-Jean Constantinesco, Traité de droit comparé, vol III: La science des droits comparés (1983), 74 .

42 Durkheim (n 28), 194 ff. 
had been its inherent elements, any explanation had to be teleological, and an analysis would have to focus either on the will of a transcendent creator or on the inherent nature of things. If institutions were defined by the purposes defined by their creators, a systematic analysis had to be impossible, for individual goals were hard to observe as well as arbitrary and contingent. The emphasis on objective functions on the other hand, distinct from both origin and purpose, allowed the search for general laws, the goal of all sciences. Still, Durkheim did think an institution's existence and its function interrelated. On the one hand, causes often determine functions: An institution is established in order to maintain a certain status quo, and it then fulfils that function. On the other hand, functions often determine if not the origin then at least the persistence of institutions: ${ }^{43}$ Dysfunctional institutions cannot compete with more efficient institutions, societies with wasteful, dysfunctional institutions cannot survive. ${ }^{44}$

Several elements of Durkheim's functionalism reappear in functionalist comparative law: the scientific character and objectivity of research, a perception of society as a whole that transcends the sum of its parts because its elements are interrelated, the idea that societies have needs, the idea that law can be understood in terms of the needs it meets, a focus on observable facts rather than individual ideas (law in action versus law in the books), the discovered similarity of institutions of different societies, and the competitive advantage of more functional institutions within one society's law and of societies with better laws vis-á-vis other societies. None the less, although Durkheim himself was a trained lawyer, his functionalism had less immediate impact on comparative law than his concept of social facts. Saleilles followed Durkheim (and Weber) in maintaining that comparative law 'cherche à définir le type d'idéal tout relatif qui se dégage de la comparaison des législations, de leur fonctionnement et de leurs résultats' and in emphasizing 'l'unité des résultats dans la diversité des formes juridiques d'application'. ${ }^{45}$ But most comparatists in the Durkheimian tradition focused rather on a non-teleological comparative legal history than on functional analysis ${ }^{46}$ and opposed more functionalist versions of comparative law. ${ }^{47}$

43 See also Wsevolod W. Isajiw, Causation and Functionalism in Sociology (1968), eg $127 \mathrm{f}$.

${ }^{44}$ Durkheim (n 28), $189 \mathrm{f}$.

45 Raymond Saleilles, 'Conception et objet de la science du droit comparé', in Congrès international de droit comparé: Procès verbaux (vol I, 1905), 167, 173, 178.

46 Roger Cotterell, 'Comparatists and Sociology', in Legrand and Munday (n 6), 131, 136 ff.

47 Pierre Lepaulle, 'The Function of Comparative Law: With a Critique of Sociological Jurisprudence', (1921-2) 35 Harvard LR 838-58; also in Zweigert and Puttfarken (n 4), 63-84. 


\section{Instrumentalism}

One reason why comparatists lacked interest in Durkheimian sociology may have been that they did not share the social scientists' fear of normativity. Instead, comparatists embraced an offspring of adaptionism that was popular in law: instrumentalism. If law fulfils functions and meets societal needs, then the lawyer's job is to develop laws that perform these tasks ('social engineering'), and comparative law can help compare the ability of different solutions to solve similar problems, and spur similar degrees of progress.

These ideas, which can be found already in Jhering's work, became prevalent in legal realism. Realism made functionalism fashionable not only in academic writing but also for curriculum reform proposals. ${ }^{48}$ One strand of realism starts from the sociological concept of function, but then translates objective functions into purposes to be set by legislatures. These realists substitute teleological analysis for Durkheim's objective science, and they assume that the effect of laws on society can be both measured and controlled. While American legal realists remained surprisingly uninterested in comparative law, European comparative law was influenced. Zweigert and Kötz put it bluntly: "Law is "social engineering" and legal science is a social science. Comparative lawyers recognize this: it is, indeed, the intellectual and methodological starting point of their discipline.' 49 Such ideas became especially attractive to the law and development movement, which hoped to use law in order to aid the economic progress of developing countries-a combination of the Darwinian faith in progress and teleology with the instrumentalist's hope placed in law. Such ideas, out of fashion for some time, ${ }^{50}$ have recently been revitalized, specifically for former communist economies, generally in the World Bank's 'Doing Business' project. ${ }^{51}$ Yet they face problems. ${ }^{52}$ First, researchers frequently place naïve faith in both the mono-functionality and effectiveness of legal institutions. Second, they are often insufficiently aware of the non-legal elements of success or failure of societies, including cultural differences. ${ }^{53}$ Experience in domestic contexts has shown that social engineering through law is far more complex than one thought; the insight still has to make its way into comparative law. ${ }^{54}$

48 Brainerd Currie, 'The Materials of Law Study, (1955) 3 Journal of Legal Education 1-78.

49 Zweigert and Kötz (n 2), 45.

50 David M. Trubek, 'Towards a Social Theory of Law: An Essay on the Study of Law and Development', (1982) 82 Yale LJ1-50.

51 www.doingbusiness.org (last accessed 21 July 2006).

52 See, most recently, Kerry Rittich, 'Functionalism and Formalism: Their Latest Incarnations in Contemporary Development and Governance Debates', (2005) 55 University of Toronto LJ 853-68.

53 Jan Torpman and Fredrik Jörgensen, 'Legal Effectiveness', (2005) 91 Archiv für Rechts- und Sozialphilosophie 515-34; Association Henri Capitant, Les droits de tradition civiliste en question-A propos des Rapports Doing Business de la Banque Mondiale vol 1 (2006).

54 A more nuanced analysis is Daniel Berkowitz, Katharina Pistor, and Jean-François Richard, 'The Transplant Effect', (2003) 51 AJCL 163-203. 


\section{Refined Functionalism}

Developments in the social sciences also contributed to their disjunction from comparative law: sociological functionalism became more complex and thereby less useful for functionalist comparative law. The work of Radcliffe-Browne, Malinowski, and Parsons has had little direct response in comparative law, mostly because their interest in a theory of societal systems was not congruent with the search in comparative law for a method. But comparative lawyers have also ignored sociologists interested in functionalism as a method. In particular, Robert Merton's seminal text on latent functions should have shown the problems of translating functionalism into comparative law. .5

First, Merton introduces the important distinction between manifest functions (functions intended and recognized by participants) and latent (unknown and unintended) functions. ${ }^{56}$ Separating objective functions from subjective intentions has a pedagogical effect: it points researchers to the importance of latent functions, which yield more important insights precisely because they previously went unrecognized. ${ }^{57}$ Comparative lawyers are sometimes in accord when they focus on what the courts do in fact, as opposed to what they say they are doing. Yet when lawyers wish to use comparative law for social engineering, they forget that legislatures cannot know latent functions precisely because these functions are only latent. Social engineering presumes unrealistically simple relations between society and laws.

A second contribution is Merton's challenge to the postulate of functional unity of society-the axiom, shared by Rabel and Zweigert, ${ }^{58}$ that societies are so integrated and interdependent that changing one element affects all others. In response, Merton suggests that different societies are integrated to different degrees and empirical tests are necessary to determine this degree. ${ }^{59}$

Merton's third challenge attacks the assumption that every element in society fulfils some vital function, ignoring non-functional or even dysfunctional institutions. Such institutions, so-called survivals, were known in both sociology and

55 Merton (n 17). An early version of the argument was published as 'Sociological Theory', (1945) 50 American Journal of Sociology 462-73.

56 Merton ( $\mathrm{n} \mathrm{17}$ ), 105, 114-36; see already idem, 'The Unintended Consequences of Purposive Social Action', (1936) 1 American Sociological Review 894-904.

57 Merton (n 17), 122.

58 See eg Ernst Rabel, 'Aufgabe und Notwendigkeit der Rechtsvergleichung', (1924) 13 Rheinische Zeitschrift für Zivil- und Prozeßrecht 279, 283; reprinted in Hans G. Leser (ed), Ernst Rabel, Gesammelte Aufsätze (vol III, 1967), 1, 5 and in Zweigert and Puttfarken (n 4), 85, 89: 'Alles das bedingt sich gegenseitig in sozialer, wirtschaftlicher, rechtlicher Gestaltung ... Alle diese vibrierenden Körper zusammen bilden ein noch von niemandem mit Anschauung erfaßtes Ganzes' (Everything in the social, economic, and legal fields interacts ... All these vibrating bodies in their ensemble form a whole that no one has yet fully realized); quoted approvingly by Zweigert and Kötz (n 2), 36.

59 Merton (n 17), 79-84. 
functionalist comparative law. ${ }^{60}$ But traditional sociologists and anthropologists, and likewise comparative lawyers, consider survivals to be unstable and only temporary. Merton in turn emphasizes that whether institutions are functional or not is a matter of empirical research, ${ }^{61}$ a point made forcefully in comparative law from an anti-functionalist perspective by Alan Watson. ${ }^{62}$

Merton's critique was powerful, while his constructive 'paradigm for functional analysis in sociology', ${ }^{63}$ was less successful. (This is similar to Felix Cohen's article on legal functionalism, ${ }^{64}$ which contains, in its first part, a brilliant critique of conceptualism, while its second part, developing a constructive theory of values, is much weaker.) Criticism of sociological functionalism grew. ${ }^{65}$ Functionalism is criticized as intrinsically teleological and therefore unable to fulfil Durkheim's own postulate of a value-free social science. ${ }^{66}$ Related to this is a criticism of implicit tautology and circularity ${ }^{67}$ mirrored in comparative law: ${ }^{68}$ The survival of societies is explained by the existence of institutions, while the existence of these institutions is explained in turn by the needs of society. For critics this means either that functional relations are no different from causal relations (and therefore dispensable as a separate category) or that teleology is reintroduced into sociology. ${ }^{69}$ Other critics go against the programme of functionalism. For them, emphasis on the stability of systems makes its proponents both politically conservative and methodologically incapable of explaining social change $\mathrm{e}^{70}$ —again, a criticism raised also

60 See eg Durkheim (n 28), 184; also Zweigert and Kötz (n 2), 35 on the non-functional German provision on 'joke transactions', $\$ 118$ BGB; ibid 634 on the dysfunctional role of $\S 831$ BGB (delictual liability for others) and functional equivalents in German law.

61 Merton (n 17), 84-6.

62 See eg Alan Watson, Legal Transplants (1974), 12-15; cf Folke Schmidt, 'The Need for a Multi-axial Method in Comparative Law', in Festschrift für Konrad Zweigert (1981), 525, 528; Frankenberg, 26 Harvard International LJ 437 f; Graziadei (n 6), 123.

${ }_{63}$ Merton (n 17), 104-8.

64 Cohen, 35 Columbia LR 809 ff. On Cohen's own concept of functionalism, akin to sociological positivism rather than to sociological functionalism, see Martin Golding, 'Realism and Functionalism in the Legal Thought of Felix S. Cohen', (1981) 66 Cornell LR 1032, $1051 \mathrm{ff}$.

65 Two influential collections of essays are Demerath and Peterson (n 17) and Don Martindale (ed), Functionalism in the Social Sciences: The Strength and Limits of Functionalism in Anthropology, Economics, Political Science, and Sociology (1965).

66 Ernest Nagel, 'A Formalization of Functionalism', in idem, Logic without Metaphysics (1965), 247 ff; reprinted in Demerath and Peterson (n 17), 77-94; Carl G. Hempel, 'The Logic of Functionalism', in Llewellyn Gross (ed), Symposium on Sociological Theory (1959), 271-307; Frankenberg, 40 Harvard International LJ 439.

67 See Turner and Maryanski (n 31), 128 ff; Mark Abrahamson, Functionalism (1978), 37 ff.

68 Vivian Curran, 'Cultural Immersion, Difference and Categories in U.S. Comparative Law', (1998) 46 AJCL 43, 67.

${ }^{69}$ Ernest Nagel, 'A Formalization of Functionalism with Special Reference to its Application in the Social Sciences', in idem, Logic without Metaphysics (1956), 247-83, reprinted in abbreviated form in Demerath and Peterson (n 17), 77-94; for a defence, see Isajiw (n 43).

70 Ralf Dahrendorf, 'Struktur und Funktion', (1955) 7 Kölner Zeitschrift für Soziologie und Sozialpsychologie 491-519; idem, 'Out of Utopia: Toward a Reorientation of Sociological Analysis', (1958) 64 American Journal of Sociology 115-27; reprinted in Demerath and Peterson (n 17), 465-80. 
against functionalist comparative law. ${ }^{71}$ And finally, and perhaps most importantly, sociological functionalism is considered unable to account for culture, in particular to explain practices that serve no function-another critique also of comparative law. ${ }^{72}$ In general, Parsons's 'grand theory' was considered too abstract and therefore often unable to predict all empirical findings, ${ }^{73}$ again a concern shared in comparative law. ${ }^{74}$

After these critiques, functionalism lost ground; a proclaimed 'neofunctionalism' has not been successful. ${ }^{75}$ Within sociology and especially social anthropology, functionalism made way for cultural and hermeneutic methods ${ }^{76}$ - a 'cultural turn' reflected in legal studies generally ${ }^{77}$ and comparative law specifically. ${ }^{78}$ At the same time, sociology as a discipline, not least due to the perceived lack of methodological sophistication, had to yield its once leading position within the social sciences to economics, again, a development replicated in comparative law. ${ }^{79}$

Legal functionalism has faced similar challenges. Already before 1900, criticism of the German Civil Code's structure as non-functional remained unheard; ${ }^{80}$ later

71 Jonathan Hill, 'Comparative Law, Law Reform and Legal Theory', (1989) 9 Oxford Journal of Legal Studies 101, 106 f; David Kennedy, 'The Methods and the Politics', in Legrand and Munday (n 6), $345,391$.

72 One author representing the trend in both anthropology and comparative law is Clifford Geertz; for anthropological anti-functionalism, see his 'Ritual and Social Change: A Javanese Example', (1957) 59 American Anthropologist 32-54; reprinted in Demerath and Peterson (n 17), 231-49; Clifford Geertz, Interpreting Cultures (1973); for anti-functionalist comparative law, see idem, 'Local Knowledge: Fact and Law in Comparative Perspective' in idem, Local Knowledge-Further Essays in Interpretive Anthropology (1983), 215-34, especially at 232. See also Pierre Legrand, 'The Same and the Different', in Legrand and Munday (n 6), 240, $292 \mathrm{f}$.

73 Wright Mills, 'Grand Theory', in idem, The Sociological Imagination (1959); reprinted in Demerath and Peterson (n 17), 171-83.

${ }^{74}$ See the references in n 6; William Alford, 'On the Limits of "Grand Theory" in Comparative Law', (1985) 61 Washington LR 945-56.

75 Jeffrey C. Alexander, Neofunctionalism and After (1998); cf Michael Schmid, 'Der Neofunktionalismus: Nachruf auf ein Forschungsprogramm', in Jetzkowitz and Stark (n 31), 279-303.

76 Victoria E. Bonnell and Lynn Avery Hunt (eds), Beyond the Cultural Turn: New Directions in the Study of Society and Culture (1999).

77 See eg Austin Sarat and Jonathan Simons (eds), Cultural Analysis, Cultural Studies and the Law: Moving beyond Legal Realism (2003).

78 The general theme for the 2007 Conference of the American Society of Comparative Law will be 'Comparative Law and Culture'.

79 For connections, see Anne Sophia-Marie van Aaken, 'Vom Nutzen der ökonomischen Theorie des Rechts für die Rechtsvergleichung', in Prinzipien des Privatrechts und Rechtsvereinheitlichung: Jahrbuch junger Zivilrechtswissenschaftler 2000 (2001), 127-49; Reinier Kraakman, Paul Davies, Henry Hansmann, Gerard Hertig, Klaus J. Hopt, Hideki Kanda, and Edward Rock, The Anatomy of Corporate Law: A Comparative and Functional Approach to Corporate Law (2004); Peter Behrens, 'Ökonomische Wirkungsanalyse im Kontext funktionaler Rechtsvergleichung' (unpublished paper delivered at the 2005 Conference of the German Society for Comparative Law in Würzburg; summary in [2006] Juristenzeitung 454).

80 Ralf Michaels, 'Strukturfragen des Schuldrechts', in Reinhard Zimmermann, Joachim Rückert, and Mathias Schmoeckel (eds), Historisch-kritischer Kommentar zum BGB (vol II, forthcoming), vor $\$ 241$, no. 50 . 
abuses of functionalism by the Nazis ${ }^{81}$ made the concept unattractive in the postwar period. Instead, the paradigm for statutory interpretation and legal argumentation moved from a functionalist jurisprudence of interests to a jurisprudence of values, thereby substituting the legislator's individual goals or a specific society's values for objective functions and abolishing the universalist aims of functionalism which had made it attractive for comparative law.

\section{Epistemological Functionalism}

All proponents of functionalism discussed so far stand before a dilemma. Either they must explain function as mere causality, or they have to insert some kind of teleology into their worldview, some 'Natur der Sache'. A way out can be found in Ernst Cassirer's functionalist epistemology. Cassirer posits that, since Kant suggested laws of nature as human constructs, there has been a seismic shift from a focus on substance to a focus on function, from attempts to understand how things 'really' are (their substance, ontology) to understanding them only in their (functional) relation to particular viewpoints (their function, epistemology). ${ }^{82}$ No longer could classes of elements be defined simply by common traits, because such an abstraction would ignore the necessary relation between the element and the whole. Rather, individual elements had to be understood in relation to particular aspects, as different results to the same function. A series of elements $a \alpha_{1} \beta_{1}, a a_{2} \beta_{2}, a a_{3} \beta_{3} \ldots$ cannot be understood merely by the common criterion $a$, but rather by the regularity in which its elements are brought about through the function $a x y$, in which the variable $x$ defines all $\alpha$, the variable $y$ defines all $\beta$, and all these elements stand in a functional regularity so that it is possible to create new elements in the series.

This move has two decisive advantages. First, it is not necessary to recognize some essence of a particular element; it is sufficient to understand the element as variable result of a functional connection with another variable element. Individual numbers do not have an essence, but the totality of all numbers does. ${ }^{83}$ Functionalism need not declare the existence of any $\alpha$ or any $\beta$ but only that if there is a certain $\alpha$ there will be a certain $\beta$. Second, it is possible to conceive of groups of elements and to describe them without the loss of specificity that comes with traditional classifications requiring abstraction. ${ }^{84}$ The function $a x y$ describes all elements of the

\footnotetext{
81 Vivian Grosswald Curran, 'Fear of Formalism: Indications from the Fascist Period in France and Germany of Judicial Methodology’s Impact on Substantive Law', (2002) 35 Cornell International LJ $101,151 \mathrm{ff}$.

82 Cassirer (n 18); for a less influential approach, see Laurence J. Lafleur, 'Epistemological Functionalism', (1941) 50 The Philosophical Review 471, 476 ff. Heinrich Rombach, Substanz, System, Struktur: Die Ontologie des Funktionalismus und der philosophische Hintergrund der modernen Wissenschaft ( $v o l 1,1965), 140 \mathrm{ff}$, sees the roots of functionalism in the work of Cusanus and Descartes.

83 Cassirer (n 18), $420 \mathrm{f}$. $\quad 84 \mathrm{cf}$ Cassirer (n 18), $18 \mathrm{ff}, 313 \mathrm{ff}$.
} 
series completely, whereas a focus on the common element $a$ as classificatory criterion would ignore both the differences between two elements $a a_{1} \beta_{1}$ and $a a_{2} \beta_{2}$ as well as the specific functional relation between $a$ and $y$ that creates the respective elements.

Although Cassirer had no direct influence on functionalist comparative law, ${ }^{85}$ several parallels exist. First, functionalist comparative law is also interested not in some essence of legal institutions, but rather in their functional relation to particular problems. Second, functionalist comparative law also aims at avoiding the abstraction inherent in both conceptual comparisons and the macro-comparison of legal families, and instead focuses on a legal institution's relation to the whole. Third, Cassirer's emphasis on the totality of elements as opposed to individual elements is akin to Max Salomon's attempt to define universal jurisprudence beyond individual national institutions. Cassirer's concept of function, which he borrowed from mathematics, can work as a formalization of functional equivalents in comparative law: If we define $a$ as a particular problem, ' $x$ ' as the variable for legal systems $\alpha_{1,2,3} \ldots$, and ' $y$ ' as the variable for legal institutions $\beta_{1,2,3} \ldots$, we can formalize the functional comparison of different legal institutions as a series, where, for example, $a \alpha_{1} \beta_{1}$ is French law's $\left(\alpha_{1}\right)$ response $\left(\beta_{1}\right)$ to problem $a$, $a \alpha_{2} \beta_{2}$ is German law's $\left(\alpha_{2}\right)$ response $\left(\beta_{2}\right)$ to the same problem $a$, and so on. This approach enables the comparatist to focus not only on the similarity between institutions (the common problem $a$ and the institutions' similar ability to respond to it) but also on the differences (between $\alpha_{1}$ and $\alpha_{2}$, and between $\beta_{1}$ and $\beta_{2}$, respectively), and furthermore allows her to explain these differences between institutions as a function (!) of the differences between legal systems. Such formalization, while raising many problems (eg whether the social sciences reveal the same degree of regularity as do mathematics and the natural sciences), is a promising step towards more rational comparative law.

\section{Equivalence Functionalism}

The insight that different elements can respond to the same problem is crucial. Finalism, adaptionism, and classical functionalism all contain traces of determinism and teleology: if similar problems cause similar solutions, then the solutions must somehow be inherent in the problems, and similar functions must be fulfilled by the same kinds of institutions. Durkheim expressly rejected functional equivalence as finalist and proclaimed a remarkable similarity between institutions of different

\footnotetext{
85 However, Max Hartmann's somewhat comparable philosophy of science did influence Georges Langrod, 'Quelques réflexions méthodologiques sur la comparaison en science juridique', (1957) 9 RIDC 353, 364 ff; reprinted in Zweigert and Puttfarken (n 4), 225, 234 ff.
} 
societies as responses to functional requirements. ${ }^{86}$ Goldschmidt's otherwise original study of comparative functionalism in anthropology claimed that 'certain social needs repeatedly call forth similar social institutions, that correlations between institutional forms can be found because, broadly speaking, they are the "natural" or "preferred" means by which certain necessary social tasks may best be performed in given circumstances' ${ }^{87}$ Even Rabel marvelled at the finding of 'essentially related institutions and developments' ${ }^{88}$

Given how different institutions are in detail, such a view is hard to maintain except in very abstract analysis; the similar institutions must be ideal types. Comparative lawyers, with their focus on details and specificities, have long known this. They knew on the one hand that similar institutions can fulfil different functions in different societies or at different times, ${ }^{89}$ and they found, on the other hand, that similar functional needs can be fulfilled by different institutions, the idea of the functional equivalent. This idea, central to functionalist comparative law, appears in all kinds of functionalism: Max Salomon's focus on problems as the unifying element of general jurisprudence enabled scholars to see different solutions as functionally equivalent; ${ }^{90}$ Josef Esser developed the concept for comparative law; ${ }^{11}$ and Konrad Zweigert made it the central point of his approach to comparative law and an important tool in seeing universalities in what may look like differences. ${ }^{92}$

Indeed, the recognition of functional equivalents gave a boost to the possibilities for comparative law. In particular, the comparison between common law and civil law has traditionally tempted functionalists, for two reasons: First, functionalist comparison overcomes the epistemic/doctrinal difference between civil and common law by declaring it functionally irrelevant. Second, the common law with its

86 Durkheim (n 28), 187: 'En fait, quand on est entré quelque peu en contact avec les phénomènes sociaux, on est ... surpris de l'étonnante régularité avec laquelle ils se reproduisent dans les mêmes circonstances. Même les pratiques les plus minutieuses et, en apparence, les plus puériles, se répètent avec la plus étonnante uniformité.' (In fact, once on gets into some contact with social phenomena, one is surprised at the astonishing regularity with which they are reproduced under the same circumstances. Even the most minute practices and the seemingly most puerile ones are repeated with the most astonishing uniformity.)

87 Walter Goldschmidt, Comparative Functionalism: An Essay in Anthropological Theory (1966), 30; see also 122: 'similar problems evoke similar solutions'.

88 Rabel, 13 Rheinische Zeitschrift für Zivil- und Prozeßrecht 284 ('wesensverwandte Einrichtungen und Entwicklungen').

89 Karl Renner, Die Rechtsinstitute des Privatrechts und ihre soziale Funktion: ein Beitrag zur Kritik des Bürgerlichen Rechts (1929; English translation under the title The Institutions of Private Law and their Social Functions by Agnes Schwarzschild, edited by Otto Kahn-Freund, 1949).

90 Salomon (n 21). $\quad 91$ Esser (n 24), especially at $354 \mathrm{ff}$.

92 Konrad Zweigert, 'Des solutions identiques par des voies différentes', (1966) 18 RIDC 5-18; for a German version, see 'Die "praesumptio similitudinis" als Grundsatzvermutung rechtsvergleichender Methode', in Rotondi (n 23), 735-58; a partial English translation can be found in Volkmar Gessner, Armin Hoeland, and Csaba Varga (eds), European Legal Cultures (1996), 160-4. 
organic development should be particularly apt for functional understanding. Not surprisingly then, some of the most influential works applying the functional method have focused on institutions from the common law and their functional equivalents in the civil law, for example trusts ${ }^{93}$ and consideration. ${ }^{94}$ Some even found functionalism helpful for intersystemic comparison between socialist and capitalist legal systems. ${ }^{95}$ Yet equivalence functionalism in comparative law has always been explicated by examples rather than developed theoretically. ${ }^{96}$ Thus, it is not clear whether functional equivalence suggests some uniformity of values beyond the universality of problems. Likewise, the concept of a function suggests a comparatively naïve relation between the problem and the institution, either between cause and effect (so that the problem causes an institution to exist), or between purpose and implementation (so that a legal solution serves the purpose of solving a recognized problem).

Here, comparative law could profit from sociological equivalence functionalism as developed especially by Niklas Luhmann (who in turn was influenced not only by Merton but also by Cassirer). Merton questioned the postulate of indispensability, according to which every element in a society is indispensable for the working of the system, and pointed out that even indispensable necessities can be met by different institutions that act as functional substitutes or functional equivalents. ${ }^{97}$ Cassirer's epistemology provided a formalized version of the argument. Functional equivalence means that similar problems may lead to different solutions; the solutions are similar only in their relation to the specific function under which they are regarded. Luhmann brings the two together to overcome a main problem of classical functionalism - the problem that functions either are nothing more than causal relations, or contain an element of teleology. Equivalence functionalism by contrast explains an institution as a possible but not necessary response to a problem, as one contingent solution amongst several possibilities. As a consequence, the specificity of a system in the presence of (certain) universal problems lies in its decision for one against all other (functionally equivalent)

93 eg Hein Kötz, Trust und Treuhand (1963); Henry Hansmann and Ugo Mattei, 'The Functions of Trust Law: A Comparative Legal and Economic Analysis', (1998) 73 New York University LR 434-79.

94 Arthur T. von Mehren, 'Civil-Law Analogues to Consideration: An Exercise in Comparative Analysis', (1959) 72 Harvard LR 1009-78; Zweigert and Kötz (n 2), ch 29-'Indicia of Seriousness'; Basil S. Markesinis, 'Cause and Consideration: A Study in Parallel', (1978) 37 Cambridge LJ 53-75; Ferdinand Fromholzer, Consideration (1997).

95 See Zweigert, 7 Israel LR 470 f; Konrad Zweigert and Hans-Jürgen Puttfarken, 'Possibilities of Comparing Analogous Institutions of Law in Different Social Systems', (1973) 15 Acta Juridica Academiae Scientiarium Hungaricae 107-30, German translation in idem (n 4), 395-429; Szabó (n 1).

96 But see now Kirsten Scheiwe, 'Was ist ein funktionales Äquivalent in der Rechtsvergleichung? Eine Diskussion an Hand von Beispielen aus dem Familien- und Sozialrecht', (2000) 83 Kritische Vierteljahresschrift für Gesetzgebung und Rechtswissenschaft 30-51.

${ }_{97}$ Merton (n 17), 86-9o. 
solutions. ${ }^{98}$ Legal developments are thus no longer necessary but only possible, not predetermined but contingent. ${ }^{99}$ This method in turn requires an understanding of society (and its subsystems, including law) as a system constituted by the relation of its elements, rather than set up by elements that are independent of each other. ${ }^{100}$ It does not avoid the criticism of tautology-institutions are still understood with regard to problems, and problems are understood as such by their relation to institutions. But because Luhmann's functionalism is constructivist, he can use these tautologies as the means by which societies constitute themselves, by which they make sense of institutions.

Although Luhmann emphasizes that 'the functional method is ultimately a comparative one'101 and occasionally suggests the comparison of systems as a valuable project of verification, ${ }^{102}$ he does not, apart from a passing reference to Josef Esser, ${ }^{103}$ use this for comparative law. Functionalist comparative law in turn has rarely reacted to Luhmann's method, ${ }^{104}$ despite the similar focus on functional equivalence. ${ }^{105}$ This is unfortunate. Of course, Luhmann's systems theory has been criticized severely-as being indifferent to individuals, inherently conservative (again), and as ignorant of the permeability of systems. Yet all these criticisms can also be launched against functionalist comparative law as it stands; they are not reasons against enriching current functionalism with Luhmann's constructivism.

98 Niklas Luhmann, 'Funktion und Kausalität', (1962) 14 Kölner Zeitschrift für Soziologie und Sozialpsychologie 617-44; reprinted in Soziologische Aufklärung (vol I, 7th edn, 2005), 1-38. For the parallel concept of equifinality, see Ludwig von Bertalanffy, 'Der Organismus als physikalisches System betrachtet', (1940) 28 Naturwissenschaften 521; idem, 'General Systems Theory', in idem, Main Currents of Modern Thought (1955), 71, 75; reprinted in Demerath and Peterson (n 17), 115, $121 \mathrm{ff}$.

99 cf Gunther Teubner, Recht als autopoietisches System (1989), $64 \mathrm{f}$ against Gordon's criticism of functionalism (n 40).

100 'Niklas Luhmann, 'Funktionale Methode und Systemtheorie'; (1964) 15 Soziale Welt 1-25; reprinted in idem (n 98), 39-67; idem, Soziale Systeme (1984), especially at 83 ff; English translation under the title of Social Systems by John Bednarz and Dirk Baecker (1995), $52 \mathrm{ff}$; cf Stefan Jensen, 'Funktionalismus und Systemtheorie-von Parsons zu Luhmann', in Jetzkowitz and Stark (n 31), 177-203.

101 See eg Luhmann, Soziale Systeme, 85 = Social Systems, 54 (both n 100); cf idem, 'Funktionale Methode und Systemtheorie' (n 100), 43 ff; idem, Die Gesellschaft der Gesellschaft (vol II, 1997), 1125 f. 102 See eg Luhmann (n 98), $31 \mathrm{f}$.

103 Luhmann, 'Funktionale Methode und systemtheorie' (n 100), 63 n 17; see also idem, Das Recht der Gesellschaft (1993), 13 f, 573 f; English translation under the title of Law as a Social System by Klaus A. Ziegert (2004), 56 f, 481.

104 A notable exception is Volkmar Gessner, 'Soziologische Überlegungen zu einer Theorie der angewandten Rechtsvergleichung', (1972) 36 RabelsZ 229-60, especially at 240 ff; reprinted in Ulrich Drobnig and Manfred Rehbinder (eds), Rechtssoziologie und Rechtsvergleichung (1977), 123-50.

105 On systems theory and autopoiesis in comparative law, see eg Lynn M. LoPucki and George G. Triantis, 'A Systems Approach to Comparing U.S. and Canadian Reorganization of Financially Distressed Companies', (1994) Harvard International LJ 267, 270 ff; Gunther Teubner, 'Legal Irritants: Good Faith in British Law or How Unifying the Law Ends Up in New Divergences', (1998) 61 Modern $L R 11 \mathrm{ff}$; Mark van Hoecke, 'Legal Orders between Autonomy and Intertwinement', in Karl-Heinz Ladeur (ed), Public Governance in the Age of Globalization (2004), 177-94; Catherine Valcke, 'Comparative Law as Comparative Jurisprudence: The Comparability of Legal Systems', (2004) 52 AJCL 713-40. 


\section{Functionalist Comparative Law: Synthesis or Eclecticism?}

Which of these concepts underlies the functional method of comparative law? The answer is: all of the above. Comparative lawyers pick and choose different concepts, regardless of their incompatibility. ${ }^{106}$ There is still a strong faith that the similarities between different legal orders revealed by the functional method are neither the result of circular reasoning, nor mere evidence of similar needs between societies, but proof of deeper universal values. While this suggests an Aristotelian background, elsewhere functionalists place themselves outside of legal philosophy and within legal sociology and emphasize objective needs over contingent values. In the concept of function itself, comparative lawyers borrow, if inadvertently, the antimetaphysical focus of epistemological functionalism as opposed to an essential concept of legal institutions; they understand institutions through their relation to problems. But it is not clear whether this concept of function is teleological or not. Sometimes comparatists use functions in an openly teleological fashion, as a way towards progress reminiscent of adaptionism - when only legal systems at similar stages of evolution are deemed comparable, ${ }^{107}$ or when the development of the law is deemed important for the discovery of its function, ${ }^{108}$ a combination of cause and function that is anathema to Durkheim's postulates. Sometimes comparatists focus on legal institutions as tools for the preservation of stability, something more akin to classical functionalism. But then it is often unclear whether they include latent functions in their focus on what laws do in effect, or whether they confine themselves to manifest functions, as in instrumentalism and social engineering. And finally, the claim that 'there will always remain ... an area where only sound judgment, common sense, or even intuition can be of any help'109 has an irrational ring to it that would, it seems, altogether distance functional comparative law from the scientific aspirations of functionalism in all other disciplines. ${ }^{110}$

In particular, the functionalism of sociology and that of law are different. First, sociologists and lawyers use different concepts of function. ${ }^{111}$ While sociological

106 See also Dimitra Kokkini-Iatridou, 'Some Methodological Aspects of Comparative Law. The Third Part of a (Pre-)paradigm', (1986) 33 Netherlands International LR 143, $168 \mathrm{ff.}$

107 Zweigert and Kötz (n 2), 3 (referring to Lambert).

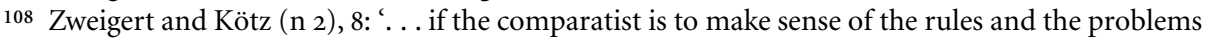
they are intended to solve he must often investigate their history'.

109 Zweigert and Kötz (n 2), 33; see also 34 ('feeling'), 35 ('imagination').

110 But see, for the possible need of irrationality for comparison, Luhmann, Soziale Systeme, $90 \mathrm{f}=$ Social Systems, $57 \mathrm{f}$ (both $\mathrm{n}$ 100) and his cite to Alfred Baeumler, Das Irrationalitätsproblem in der Ästhetik und Logik des 18. Jahrhunderts bis zur Kritik der Urteilskraft (1923, reprinted 1967), $141 \mathrm{ff}$.

111 Niklas Luhmann, 'Funktionale Methode und juristische Entscheidung', (1969) 94 Archiv für öffentliches Recht 1-31; reprinted in idem, Ausdifferenzierung des Rechts (paperback edn, 1999), 273-308; Hans - Joachim Bartels, Methode und Gegenstand intersystemarer Rechtsvergleichung (1982), 77-9; cf also Jean Carbonnier, 'L'apport du droit comparé à la sociologie juridique', in Livre du Centenaire (n 2), 75, 77-9; Jerome Hall, Comparative Law and Social Theory (1963), 107; Zweigert and Kötz (n 2), 11 f N.A. Florijn, Leidraad Voor Zinvolle rechtsveigelijking (1995), 45. 
functionalism is interested in latent functions (and largely ignores the intention of lawmakers), lawyers focus precisely on manifest or even imagined as opposed to latent functions: The judge must interpret a statute according to the function intended by the legislator even if the statute is dysfunctional; the legislator can consider only manifest functions because by definition he does not know about latent functions. ${ }^{112}$ Sociologists could be said to take an external, and lawyers an internal point of view. ${ }^{13}$ Second, the goals of functionalism in sociology and law are different. This is only partly due to the difference between normative and descriptive analytical goals - after all, a large part of the judge's task is descriptive, too. ${ }^{114}$ Rather, sociologists use functionalism in order to raise complexity, so their picture of observed societal systems becomes more accurate than a mere listing of its elements. Lawyers, on the other hand, use functionalism to reduce complexity-they hope for functionality to tell them which of several alternative decisions they should take. ${ }^{115}$ The effects of judicial decisions are only partly the responsibility of judges; ${ }^{116}$ even legislators must take decisions in necessary partial ignorance of effects. Finally, sociologists and legal philosophers often focus on the differentiated functions of relatively broadly defined institutions, while comparative lawyers take the existence and functionality of law for granted and focus on very specific legal issues.

The clash between sociological and legal concepts of comparative law is sometimes observable-when Roscoe Pound's sociological comparative law is criticized from the Durkheimian tradition as unsociological, ${ }^{117}$ when a lawyer rejects a questionnaire proposal by a sociologist as too unspecific and too oblivious of legal categories, ${ }^{118}$ or when Zweigert's concept of functional comparative law is criticized by lawyers as not sufficiently legal and by sociologists as not sufficiently sociological. ${ }^{119}$ Whereas sociological functionalism has been criticized as inherently conservative, legal functionalism and social engineering have been rejected as overly progressive and activist. Whereas sociological functionalism is rejected as tautological, legal functionalism is criticized for its open introduction of new values into legal arguments. A big interdisciplinary project at the Hamburg

\footnotetext{
112 Of course, lawmakers may learn about latent functions over time. Sunset clauses for legislation are a response to the problem: lawmakers make laws, then observe their latent functions and dysfunctions, and then react to this learning experience.

113 William M. Evan, Angelo Grisoli, and Renato Treves, 'Socialogia del divitto e divitto comparato-Considerazione conclusive', (1965) Quaderni di sociologia 376, 389 (quote by Traves); German translation in Drobnig and Rehbinder (n 104), 34, 51.

114 See Ralf Michaels and Nils Jansen, 'Die Auslegung und Fortbildung ausländischen Rechts', (2003) 116 Zeitschrift für Zivilprozeß 3, 8-12.

115 Luhmann (n 98), 10, 6; cf Gessner, (1972) 36 RabelsZ 247 f.

116 See Gunther Teubner (ed), Entscheidungsfolgen als Rechtsgründe: Folgenorientiertes Argumentieren in rechtsvergleichender Sicht (1995).

117 Lepaulle, 35 Harvard LR 838-58. 118 Evan et al (n 113).

119 Keebet von Benda-Beckmann, 'Einige Bemerkungen über die Beziehung zwischen Rechtssoziologie und Rechtsvergleichung', (1979) 78 Zeitschrift für vergleichende Rechtswissenschaft 51-67; Gessner, 36 RabelsZ 229, $240 \mathrm{ff}$.
} 
Max Planck Institute involving both sociologists and lawyers largely failed due to these incompabilities; the interaction between sociology and comparative law has focused more on empirical sociology than on theory. ${ }^{120}$

One reason for the methodological mishmash in comparative law is that the founders of the functional method were more pragmatically than methodologically interested. In suggesting, almost in passing, that the function of institutions has to stand at the centre of the comparative endeavour, ${ }^{121}$ Ernst Rabel did not develop an elaborate method from this insight. His approach was deliberately pragmatic rather than theoretical; he was not interested in expansive methodological debate, ${ }^{122}$ but in solving practical problems. Ascribing a 'functional method' to him was rather the work of his student Max Rheinstein, who introduced his thoughts to the United States. ${ }^{123}$ Josef Esser came closer to developing an elaborate functional method, but his influence did not extend to the details of the method, and few would have shared his philosophical foundations. Konrad Zweigert, ${ }^{124}$ despite the disdain for methodological debates uttered in his textbook, published quite extensively on methodological questions. Yet he was driven primarily by an interest in universalist humanism and in legal unification; the functional method was simply the best tool to reach these goals.

Methodological eclecticism could be justified as pragmatism. But it has invited criticism, and functionalist comparatists react surprisingly defensively. One defensive strategy is to acknowledge the relevance of culture as an add-on for functionalist comparative law. Yet with no clear view of the relationship between culture and function, this must lead to an eclectic, internally inconsistent method. Another strategy is to postulate a 'methodological pluralism' in which functionalism is only one of several methods, and the comparatist picks (ad hoc?) whichever method seems most appropriate for a given purpose. ${ }^{125}$ Neither strategy seems promising unless the strengths and weaknesses of a more clearly functional method are recognized. If the functional method is deficient, it is not clear why a moderated version

120 Michael Martinek, 'Wissenschaftsgeschichte der Rechtsvergleichung und des Internationalen Privatrechts in der Bundesrepublik Deutschland', in Dieter Simon (ed), Rechtswissenschaft in der Bonner Republik (1994), 529, $552 \mathrm{f}$.

121 Rabel, 13 Rheinische Zeitschrift für Zivil- und Prozeßrecht 282; also in Zweigert and Puttfarken (n 3), 88.

122 Max Rheinstein, 'In Memory of Ernst Rabel', (1956) 5 AJCL 185, 187; cf Hans G. Leser, 'Ein Beitrag Ernst Rabels zur Privatrechtsmethode: "Die wohltätige Gewohnheit, den Rechtsfall vor der Regel zu bedenken" ', in Festschrift für Ernst von Caemmerer (1978), 891-906; David J. Gerber, 'Sculpting the Agenda of Comparative Law: Ernst Rabel and the Façade of Language', in Annelise Riles (ed), Rethinking the Masters of Comparative Law (2001), 190, $196 \mathrm{ff}$.

123 Rheinstein, 2 University of Chicago LR 246-50, especially at $248 \mathrm{f}$.

124 Rabel's importance for Zweigert becomes clear in von Caemmerer, Zweigert (n 2). Zweigert wrote a short foreword for Esser's book; see Esser (n 24), VII.

125 See eg Jaakko Husa, 'Farewell to Functionalism or Methodological Tolerance?', (2003) 67 RabelsZ 419, 446 f; Palmer, 53 AJCL 290; see also A.E. Onderkerk, De preliminaire fase van het rechtsvergelijkend onderzoek (1999) $79 \mathrm{ff}$. 
should be maintained; if it is not deficient, it is unclear why it should be moderated. Yet we cannot evaluate this as long as we lack a coherently formulated functional method, with a consistent concept of function.

\section{FUnCTIONS OF FUnCTION}

One could thus be excused for thinking functionalist comparative law indefensible. The functional method has turned out to be an undertheorized approach with an undefined disciplinary position, assembling bits and pieces from various different traditions, which, while mutually incompatible, are similar in their decline. But to think so would be hasty. If the substance of a functional method in comparative law is unclear, our analysis should move from a substantive to a functional one and focus on what it does, instead of what it is. In the spirit of Durkheim and Merton, we should measure the method neither by its origins nor by the intentions of its proponents, but by its functionality. We should look at the functions and dysfunctions of the concept of function, including its latent functions, in the production of comparative law knowledge. We should look at whether it is functional or dysfunctional, and we should see whether alternative proposals could serve as functional equivalents. This should enable us at the same time to start reconstructing the functional method as a constructive, interpretative, ${ }^{126}$ rather than positive enterprise, as a way of making sense of legal systems-constructing them as meaningful, instead of merely measuring them. Of course, such a method must use the same concept of functionalism throughout. I propose to use equivalence functionalism, both because it is the most robust concept in sociology and because it represents the central element of functionalist comparative law as developed by Rabel and Zweigert: functional equivalence.

This section focuses on seven functions: (1) the epistemological function of understanding legal rules and institutions, (2) the comparative function of achieving comparability, (3) the presumptive function of emphasizing similarity, (4) the formalizing function of system building, (5) the evaluative function of determining the better law, (6) the universalizing function of preparing legal unification, and (7) the critical function of providing tools for the critique of law.

126 Otto Pfersmann, 'Le droit comparé comme interpretation et comme théorie du droit', (2001) 53 RIDC 275-88; see also Anne Peters and Heiner Schwenke, 'Comparative Law beyond PostModernism', (2000) 49 ICLQ 800, $833 \mathrm{f}$. 


\section{The Epistemological Function: Understanding Law}

The first function of function is epistemological. Functionalism provides a tool to make sense of the data we find. We understand this function of function if we distinguish functionalist comparative law from an approach that shares some of its methodology and is often referred to as functionalist: the factual method, ${ }^{127}$ especially as applied in common core research. ${ }^{128}$ There are two important differences that strip the factual method of much of the explanatory power that functionalism claims for itself and that suggest that the factual method and common core research should not be called functionalist. ${ }^{129}$ First, the factual method shows us similarities across legal systems, but it does not tell us whether these are accidental or necessary, or how they relate to society. Second, the factual method, in focusing on cases, is limited in two ways: its problems are only disputes, and its solutions are only court decisions. Functionalism promises more. It aims at explaining the effects of legal institutions as functions (a specific kind of relation), and it promises to look at non-legal responses to societal requisites, too. The functional method asks us to understand legal institutions not as doctrinal constructs but as societal responses to problems-not as isolated instances but in their relation to the whole legal system, and beyond, to the whole of society.

This suggests why a frequent criticism of functionalism as being too rulecentred ${ }^{130}$ may apply to much mainstream comparative law, but not to the functional method. Functionalists explicitly ask that comparatists look not only at legal rules ('law in books'), nor only at the results of their application ('law in action'), but even beyond at non-legal answers to societal needs. ${ }^{131}$ Few comparatists may practise this, but this is a flaw in practice, not in the method. Similarly, the frequent criticism that functionalism is reductive ${ }^{132}$ is unwarranted. The great advantage of functionalism over substantivism, emphasized first by Cassirer, is precisely that it makes generalizations possible without loss of specificity. ${ }^{133}$ Functionalism emphasizes relations in addition to institutions, and it focuses on latent in addition to manifest functions. In this sense, a functionalist view of legal institutions, focusing on the complex interrelatedness of societal elements, creates a picture not less but more complex than that created by the participants in a legal system. ${ }^{134}$

\footnotetext{
127 eg Stefan Rozmaryn, 'Etude comparative de cas administratifs concrets', (1967) 19 RIDC 421-4.

128 Rudolf Schlesinger (ed), Formation of Contracts: A Study of the Common Core of Legal Systems (vol I, 1968), 30-41.

129 cf Ralf Michaels, 'Common Core?', ERPL (forthcoming).

130 Frankenberg, 26 Harvard International LJ 438; Graziadei (n 6), 110; Rosen (n 12), 504; Constantinesco (n 41), 69-70: 'Begriffsjurisprudenz' (conceptual jurisprudence).

131 See eg Ascarelli (n 2), 30, 40; Zweigert and Kötz (n 2), 38 f.

132 See eg Mark Tushnet, 'The Possibilities of Comparative Constitutional Law', (1999) 108 Yale LJ $1225,1265 \mathrm{ff}$.

133 Above pp 355 f. $\quad{ }^{134}$ Luhmann, Soziale Systeme, $88=$ Social Systems 56 (both n 100).
} 
The same is true for the criticism that functionalism makes no room for culture. ${ }^{135}$ Rightly understood, functionalist comparative law assumes that legal rules are culturally embedded, especially once latent functions are accounted for. In fact, functionalists can sound like their critics: 'Le fait que tout droit est un phénomène culturel et que les règles de droit ne peuvent jamais être considérées indépendamment du contexte historique, social, économique, psychologique et politique est confirmé avec une force particulière par les enquêtes de droit comparé';136 'cette méthode fonctionnelle ... permet d'atteindre ... le système dans son homogénéité, dans son esprit, dans ce qu 'on a justement appelé sa "mentalité" . . .' 137 What distinguishes functionalists from culturalists is not the degree of attention to culture, but the kind of attention. What critics call acultural is the functionalists' resistance to adopting an insider's view, their unwillingness to limit themselves to culture as such, and of course their reconstruction of culture as functional (or dysfunctional) relations. This can of course account for only one aspect of culture. But once the futile hope to grasp any holistic 'essence' of culture is given up, a functionalist outsider's account need not be inferior to a culturalist insider's account; it just highlights a different perspective. To do so, functionalism must assume that 'law' can somehow be separated from 'society' because otherwise law could not fulfil a function for society. This assumption of separability has been criticized, ${ }^{138}$ but it can be defended at least as a heuristic device. The separation is more in tune with both the use of the term 'law' and the functional differentiation of modern societies; it carries more analytical force than collapsing all law into society and culture would.

Obviously, functionalism is not the only available epistemological scheme for understanding a legal system. ${ }^{139}$ Functionalists take an observer's perspective as an alternative to, not a substitute for, the participant's perspective inherent in cultural approaches, and emphasize the view of law in a specific (namely functional) relation, while ignoring other relations. Functionalism can thus not claim to capture some essence or 'ultimate truth' of legal institutions; ; 140 but such a claim would run counter to its own programme, anyway. Functionalism in sociology as in philosophy is the fruit of a move away from metaphysical concepts like 'substance' and 'essence'; function is not an ontological category. Such a functionalist comparative law, driven by a particular interest of the comparatist, cannot be fully objective and

135 Above, $\mathrm{n} 72$.

136 Zweigert, 18 RIDC (n 92), 13 f. 137 Ancel, 'Problème' (n 1), 4.

138 cf Frankenberg, 26 Harvard International LJ 424; Gordon, 36 Stanford LR 102 ff; Geoffrey Samuel, 'Epistemology and Comparative Law: Contributions from the Sciences and Social Sciences', in Mark van Hoecke (ed), Epistemology and Methodology of Comparative Law (2004), 35, $39 \mathrm{ff}$.

139 Geoffrey Samuel, Epistemology and Method in Law (2003), $301 \mathrm{ff}$.

140 Graziadei (n 6), 112. 
neutral in the way traditional sciences aim at objectivity and neutrality, ${ }^{141}$ but this is not a shortcoming.

If functions are relations between institutions and problems, then the first task is to find the problem to be solved by legal institutions. And this is itself a problem. ${ }^{142}$ For evolutionists, a problem is a situation in society that spurs legal and ultimately social change; the solution is only a temporary step forward that will lead to new problems. For neo-Kantians, a problem is a legal problem ('Rechtsproblem') and thus a problem defined by the law and not by social reality, an aprioristic philosophical concept. ${ }^{143}$ A solution cannot be found in an analogy to the sciences because it requires a value judgment. ${ }^{144}$ For functionalists, finally, a problem is only one side of a bipolar functional relation, the other side taken by the institution that meets the need, so society can stay in equilibrium: problems and institutions mutually constitute each other.

There are real issues with functionalism as a social science or as philosophy, but less so for constructivist functionalism in comparative law. Explaining legal institutions functionally drives hypotheses that consider the problems and the structure of a society not as realities (either empirical or philosophical), but rather make proposals about how societies can and should be understood, not just how they work. That a problem exists and that an institution is a response to it need not be proven; but the connection between events and institutions must be made plausible as a way of understanding. We may well say that problems are constructed ${ }^{145}$ and still maintain explanatory power; we may analyse from a particular non-universal viewpoint and offer this analysis as one of several possible interpretations. Functionalism thereby turns from a scientific to a constructive approach to law, a way of 'making sense' that is distinct from the participants' way of making sense of their legal systems. This would be problematic for a positive science. It is not so for an argumentative and normative, purpose-oriented discipline like comparative law.

\footnotetext{
141 Frankenberg, 26 Harvard International LJ 439; Mark van Hoecke and Mark Warrington, 'Legal Cultures, Legal Paradigms and Legal Doctrine: Towards a New Model for Comparative Law', (1998) 47 ICLQ 495, 535; Husa, 67 RabelsZ 443.

142 Gessner, 36 RabelsZ 232 ff; Hans F. Zacher, 'Vorfragen zu den Methoden der Sozialrechtsvergleichung', in idem (ed), Methodische Probleme des Sozialrechtsvergleichs (1977), 21, 41 ff; Hill, 9 Oxford Journal of Legal Studies 108; Onderkerk (n 125) 70 ff; Teemu Ruskola, 'Legal Orientalism', (2002) 101 Michigan LR 179, 189 f. See already Ernst von Hippel, Book Review of Salomon (n 21), (1926) 49 Archiv des öffentlichen Rechts 274, 279 f.

143 See Arwed Blomeyer, 'Zur Frage der Abgrenzung von vergleichender Rechtswissenschaft und Rechtsphilosophie', (1934) 8 Rabels $Z_{1}$, especially at $12 \mathrm{f}$.

144 Salomon (n 21), $51 \mathrm{ff}$.

145 Luhmann, Soziale Systeme 86 = Social Systems 54 (both n 100); Florijn (n 111) 45; Nils Jansen, 'Dogmatik, Erkenntnis und Theorie im europäischen Privatrecht', (2005) 13 Zeitschrift für Europäisches Privatrecht 750, 772.
} 


\section{The Comparative Function: Tertium Comparationis}

Of course, this interpretative reconstruction of functionalism immediately raises the question why one functional explanation should be more plausible than another. How can functions be tested empirically? How can we prove values? Comparison can help here, and this leads to the second function of function-that of tertium comparationis.

Comparison traditionally requires an invariant element. In theory, a functional method could set either problems or institutions as invariant; ${ }^{146}$ in reality, as long as institutions are non-universal, only problems can play the role of a constant. Functionalists often claim that comparative law can serve as the closest substitute for an experiment to test a hypothesis on functional relations. ${ }^{147}$ Yet this still begs the question whether needs and problems are universal. ${ }^{148}$ It is not even clear what universality of problems means: Philosophers like Max Salomon understand these problems as philosophically universal problems of general jurisprudence, while the sociological strand understands them as empirically universal problems of societies. As a consequence, it is not clear whether function as tertium comparationis refers to (manifest) value judgments by legislatures or to (latent) sociological needs or, as Rabel said somewhat opaquely, to both. ${ }^{149}$ In addition, sociologists and anthropologists who define substantive problems often fall into one of two traps. ${ }^{150}$ Either their lists of societal needs ${ }^{151}$ are too abstract for meaningful comparative law-the stability of society is relevant on a different level than the enforcement of

146 Luhmann (n 98), 21; Scheiwe, 83 Kritische Vierteljahresschrift für Gesetzgebung und Rechtswissenschaft $30 \mathrm{n} 2$.

147 Lepaulle, 35 Harvard LR 853 f; reprinted in Zweigert and Puttfarken (n 3), 77 f ('recoupement'); Roscoe Pound, 'Some Thoughts about Comparative Law', in Festschrift für Ernst Rabel (1954) 7, 12 f; similarly Merton (n 17), 108.

148 Watson (n 62), 4 f; Jerome Hall (n 111), 108-10; Constantinesco 63 ff; Wolfgang Mincke, 'Eine vergleichende Rechtswissenschaft', (1984) 83 Zeitschrift für vergleichende Rechtswissenschaft 315, 324; Richard Hyland, 'Comparative Law', in Dennis Patterson (ed), A Companion to Philosophy of Law and Legal Theory (1996), 184, 189; de Cruz (n 1), 228-30; James Q. Whitman, 'The Neo-Romantic turn', in Legrand and Munday (n 6), 312, 313.

149 Ernst Rabel, 'El fomento internacional del derecho privado', (1931) 18 Revista de derecho privado 321, 331; reprinted in Gesammelte Aufsätze (n 58, vol III) 35, 50: 'el tertium comparationis, constituido de un lado por las intenciones sociales económicas y éticas de las leyes, y de otro por las exigencias practicas de la vida que se presentan como parecidas entre sí' (the tertium comparationis, constituted on the one hand by the law's social, economic, and ethical purposes, on the other hand by the practical exigencies of life as they similarly present themselves). See also idem, 'In der Schule von Ludwig Mitteis', (1954) 7-8 Journal of Juristic Papyrology 157, 159; reprinted in Gesammelte Aufsätze (n 58, vol III) 376, 378: 'die funktionelle Betrachtung-die man auch die soziale, aber am wichtigsten die juristische nennen konnte ...' (the functional analysis-which could also be called social, but most importantly juristic..).

150 Tushnet, 108 Yale LJ 1238.

151 eg D. F. Aberle, A. K. Cohen, A. K. Davis, M. J. Levy, Jr, and F. X. Sutton, 'The Functional Prerequisites of a Society', (1950) 6o Ethics 100-11; reprinted in Demerath and Peterson (n 17), 317-31; cf Marion Levy, The Structure of Society (1950), 34-55. 
consumer rights. Or problems are contingent on specific societal structures and thus no longer universal ${ }^{152}$ — the problem of protecting shareholder rights will not exist in societies without capital markets. For example, we may think that societies require deterrence of wrongdoing and that tort law is there to fulfil this need. But how do we know that this is the problem that tort law solves? Why is its function not compensation, instead, or the effectuation of certain societal values? Or is tort law perhaps even dysfunctional?153

Some comparatists try to avoid these challenges by restricting the analysis to societies at similar stages of development and in certain relatively value-neutral areas of the law. ${ }^{154}$ Yet not only have such more complex comparisons been made frequently. ${ }^{155}$ Also, the restriction to societies at the same stage of development smacks of the now-discarded functional adaptionism; and the restriction to valueneutral areas of the law assumes the similarity of problems precisely by designating areas of the law as value-free and therefore non-contingent.

It seems more fruitful to differentiate between levels of analysis. We can assume relatively safely that certain abstract problems - for example, the need to surviveare universal, at least in the sense that all societies face them qua being societies. ${ }^{156}$ Such general problems cannot simply be broken down into the specific problems that interest comparative lawyers by mere deduction, just as discussions about the function of law in general do not yield answers addressing the functions of specific legal institutions. Many problems are contingent on the solutions to other problems. ${ }^{157}$ But they enable the comparatist who does not find universality of a certain problem at a high degree of specificity to step down one level because derived needs arise, if in a contingent way, from original needs. The more specific a problem is, the less likely its universality, but a focus on the more general level enables us to see not only the contingency of certain problems but also what the analogous problems in other legal systems are. This leads to a much more complex, but also a richer, functional analysis.

Furthermore, functionalist epistemology makes it unnecessary to assume universal problems. Once the formulation of a problem is understood as a constructive move rather than an empirical one, the universality of problems is likewise a constructive move rather than a mere representation of reality. Comparability is

152 Goldschmidt (n 87), 106 ff.

153 Nils Jansen, Binnenmarkt, Privatrecht und europäische Identität (2004), $67 \mathrm{ff}$. For another example, see Iain D.C. Ramsay, 'Functionalism and Political Economy in the Comparative Study of Consumer Insolvency: An unfinished story from England and Wales' (2006) 7 Theoretical Inquiries in Law 625, 632 ff.

154 See eg Zweigert (n 92), 756.

155 See the examples given by Graziadei (n 6), $109 \mathrm{f}$; cf also the criticism by Frankenberg, 26 Harvard International LJ 437 f; Constantinesco (n 41), n 40.

156 Wilbert E. Moore and Joyce Sterling, 'The Comparison of Legal Systems: A Critique', (1985) 14 Quaderni fiorentini per la storia del pensiero giuridico 77, 98; cf Goldschmidt (n 87), 118 ff.

157 Goldschmidt (n 87), 106 ff. 
attained through the construction of universal problems as tertia comparationis. This is where the notion of functional equivalent has its bite. Even if legal institutions are understood as responses to societal needs, they are not caused by these needs in the sense of logical necessity. Rather. They are contingent responses to these needs that can be identified with reference to the other possible responses, the functional equivalents, that were not chosen. ${ }^{158}$ These functional equivalents may not be known until they appear in other legal systems, but their appearance enables the comparatist to construct the underlying problem and thereby to recognize the functions of a legal institution. The similarity of results to certain fact situations, regardless of differences in doctrine, strongly suggests that the respective legal institutions can be seen as different (but functionally equivalent) responses to a similar problem. This reasoning is of course circular-it goes from problems to functions and from functions to problems. But this circularity resembles the way in which mathematicians recognize functions, and it appears justified for constructivist comparative law as interpretation because it mirrors the hermeneutic circle between the comparatist and the legal systems observed that is characteristic of comparative law. ${ }^{159}$

\section{The Presumptive Function: Praesumptio Similitudinis}

The universality of problems leads to the question of difference and similarity. Zweigert suggested the (in)famous praesumptio similitudinis, a presumption of similarity: The comparatist should assume that different societies face similar needs and that, to survive, any one society must have (functionally equivalent) institutions that meet these needs. As a consequence, if the comparatist finds no functional equivalent in a foreign legal order, he should 'check again whether the terms in which he posed his original question were indeed purely functional, and whether he has spread the net of his researches quite wide enough'.160

Perhaps no statement in the history of comparative law has been criticized more than this short passage. Three types of this criticism deserve attention here. First, the postulate violates requirements of scientific method: Following Popper's critical rationalism, the comparatist should try not to prove but to falsify hypotheses. ${ }^{161}$ Second, the postulate violates requirements of ideological neutrality, or requirements of the correct ideology: The comparatist should not favour similarity over difference, but should either be objective and neutral as between similarity and difference or should even openly advocate difference over

\footnotetext{
158 See above, pp 358 f. $\quad 159$ cf Zacher (n 142), 39 f; Ruskola, 101 Michigan LR 232 f.

160 Zweigert and Kötz ( $\mathrm{n}$ 2), 40; for an earlier version see already Zweigert, 'Praesumptio Similitudinis' (n 92) $755 \mathrm{f}$. Zweigert first mentioned the praesumptio in 'Méthodologie' (n 2), $297=$ 'Zur Methode' (n 2), 198.

161 von Benda-Beckmann, (1979) 78 Zeitschrift für vergleichende Rechtswissenschaft 57.
} 
similarity. ${ }^{162}$ Third, the postulate is reductionist: Similarity will only appear once legal orders or institutions are stripped of culturally relevant and contingent details. ${ }^{163}$ Some defendants of functionalism yield to the critique; they are ready to give the presumption up. ${ }^{164}$ But things are not that easy.

First, the presumption of similarity must be placed in its historical context. It was formulated after a war had been fought on the allegation of insurmountable differences; this is one reason why comparatists tried to counter the presumption of difference prevailing among ordinary lawyers of that time. ${ }^{165}$ In this sense, the presumption of similarity was as critical of the state of affairs of its time as is the current emphasis on difference, which may likewise be just a rhetorical strategy. ${ }^{166}$ Calls for 'falsification' of the presumption are, then, as misplaced as calls for a switch to a praesumptio dissimilitudinis because they only shift the relation between rule and exception. ${ }^{167}$

More to the point, the presumption is closely linked to the methodological assumptions. If only functionally equivalent institutions are comparable, then by definition these institutions must be similar in the sense that they respond to the same problem. To this extent, the presumption is not just Zweigert's naïve idea, but a necessary element of functionalist comparative law. Here the caveat that only societies at similar stages and institutions in value-neutral areas of the law can be compared becomes important. Of course, this caveat turns the assumption into a tautology: problems are universal in so far as we exclude all problems that are not universal. ${ }^{168}$ But this tautology is not fatal once we understand functionalism as a constructive method: it describes the thought process between the general and the specific, between presumed problems and institutions as presumed responses, that creates legal knowledge. The claim of universality of a problem is a first interpretative step that can be challenged, but this is a fruitful way of making sense of one legal system in relation to another.

If therefore the presumption of similarity is central to the functional method, it

162 Curran, 46 AJCL 67; Pierre Legrand, Le droit comparé (1999), 110: 'principium individuationis'; Hyland (n 148), 194: 'coniectura dissimilitudinis'.

163 Geertz, 'Local Knowledge' (n 72); Volkmar Gessner, 'Praesumptio similitudinis?-A Critique of Comparative Law', in 1995 Annual Meeting of the ISA Research Committee on Sociology of Law 'Legal Culture: Encounters and Transformations', Section Meetings, August 1-4, 1995 (1995), 41, 50: 'the praesumptio similitudinis is nothing but a consequence of poor data collection in comparative legal studies'; see already idem, 36 Rabels $Z 235$.

164 See eg Ancel, Utilité (n 1), 55 ff; de Cruz (n 1), 230; Husa, 67 RabelsZ 440 f, 442 f; cf Hein Kötz, 'The Common Core of European Private Law: Presented at the Third General Meeting of the Trento Project', (1998) 21 Hastings International and Comparative LR 803, 807, slightly revised from (1997) 5 ERPL 549, 552: 'must be rebutted when there is evidence for doing so'; see also Ruskola, 101 Michigan LR 191.

165 Curran, 46 AJCL $67 \mathrm{ff}$. 166 Thus Legrand (n 72), 302; see also Husa, 67 RabelsZ $442 \mathrm{f}$.

167 cf Nathaniel Berman, 'Aftershocks: Exoticization, Normalization and the Hermeneutic Compulsion', (1997) Utah LR 281-6.

168 Hiram Chodosh, 'Comparing Comparisons: In Search of Methodology', (1999) 84 Iowa LR $1025,1122 \mathrm{f}$. 
becomes vital to understand clearly what the presumption does and does not say. What is presumed to be similar are neither the legal institutions, nor the problems to be solved by them and the need for societies to respond to them, but the functional relation between problems and solutions: if a society has a certain problem $a$, it must have a legal institution $y$, and different solutions to $a$ are functionally equivalent. This does not mean that different solutions to similar problems, the core element of the functional method, are really 'similar'; Zweigert's own formulation of 'similarity' is misleading. Tort law and insurance law are not similar just because they fulfil the same function of providing accident victims with compensation for their accidents. They are obviously different-not only in their doctrinal structures but also (a point often neglected by comparatists) in their effects and functions (or dysfunctions) regarding problems other than that of compensation, such as deterrence, the creation of certain kinds of jobs (judges or insurers), litigiousness, or a welfare mentality. They are similar regarding only one element-namely, the solution of one specific problem. This is not similarity. This is functional equivalence. ${ }^{169}$

Some critics consider the praesumptio similitudinis to be internally inconsistent, because comparatists claim that different legal systems find similar results although at the same time they advocate differences between the legal institutions they compare. ${ }^{170}$ They are partly right. Comparatists do indeed look at difference and similarity at the same time, but that is not inconsistency. Rather, functional equivalence is similarity in difference; it is finding that institutions are similar in one regard (namely in one of the functions they fulfil) while they are (or at least may be) different in all other regards-not only in their doctrinal formulations, but also in the other functions or dysfunctions they may have besides the one on which the comparatist focuses. The decision to look at a certain problem, and thus at a certain function, therefore becomes crucial for finding similarity. But this is always similarity regarding only that one function. The finding of similarity is contingent on the comparatist's focus.

It follows that this degree of similarity cannot explain a whole institution. First, by choosing one institution $\beta_{1}$ a society decides against other possible functionally equivalent institutions $\beta_{2}$ and $\beta_{3}$. The choice of tort law for compensation purposes is, at least in part, a choice against insurance law for the same purposes. It would therefore be wrong to say that 'really' tort law and insurance are the same, because this would strip the decision for one and against the other institution of its relevance. Second, when the comparatist uses one function as his tertium comparationis, he deliberately leaves other functions out of his view for which

\footnotetext{
169 cf Scheiwe, 83 Kritische Vierteljahresschrift für Gesetzgebung und Rechtswissenschaft 35; Hein Kötz, 'Abschied von der Rechtskreislehre?', (1998) 6 Zeitschrift für Europäisches Privatrecht 493, 504 f.

170 Hill, 9 Oxford Journal of Legal Studies 103, 109; cf Frankenberg, 26 Harvard International LJ 440.
} 
institutions may well be different. ${ }^{171}$ In so far as functional equivalence means similarity regarding one function, the presumption is tautological: ${ }^{172}$ because only institutions fulfilling the same function are comparable, by definition they must be similar regarding their quality of fulfilling this function. Nothing is said about any further similarity or difference. Because critics have spilled much ink on a misunderstanding, this insight deserves repeating: Functionalism leads to comparability of institutions that can thereby maintain their difference even in the comparison. It neither presumes, nor does it lead to, similarity.

\section{The Systematizing Function: Building a System}

As a last step in the comparative method, Zweigert proposes the 'building of a system' with its own 'special syntax and vocabulary'. ${ }^{173}$ How is it possible to do so, given that 'comparative law is by its nature a functional and antidoctrinal method'? ${ }^{174}$ Must such a system not necessarily be as formalist and as doctrinal as the national systems that the functional methods try to overcome? ${ }^{175}$

In one way the answer is yes: scientific approaches aim at building systems, and systems are by their nature formalist. We see this development in social anthropologists who hoped that function would lead to a general heuristics of societies and societal systems; in sociologists like Parsons who developed his elaborate AGIL system; ${ }^{176}$ and in legal philosophers who linked comparative law to the systembuilding project of general jurisprudence. All these system-building projects have been criticized as being insensitive to details and as technocratic.

171 Luhmann (n 98), 25: 'Einzelne funktionale Leistungen sind nur in einer bestimmten analytischen Perspektive äquivalent' (individual functional achievements are equivalent only from a specific analytical perspective); Scheiwe, 83 Kritische Vierteljahresschrift für Gesetzgebung und Rechtswissenschaft $36 \mathrm{f}$.

172 For this criticism, see Scheiwe, 83 Kritische Vierteljahresschrift für Gesetzgebung und Rechtswissenschaft 34, 35 .

173 Zweigert and Kötz (n 2), 44-6; Max Rheinstein, 'Teaching Comparative Law', (1937-8) 5 University of Chicago $L R$ 615, $620 \mathrm{f}$. For problems of systematization and terminology in a practical example of functionalist comparative law, see Ulrich Drobnig, 'Methodenfragen der Rechtsvergleichung im Lichte der "International Encyclopedia of Comparative Law" ', in Ius Privatum GentiumFestschrift für Max Rheinstein (1969), 221, 228-33. The prominent position of the system in Zweigert and Kötz's treatise may be due to Zweigert's interest in a system of comparative law before he advocated functionalism. See eg Konrad Zweigert, Book Review, (1949) 15 RabelsZ 354-8; Bernhard C. H. Aubin and Konrad Zweigert, Rechtsvergleichung im deutschen Hochschulunterricht (1952), eg at 39 ('Einheit eines überpositiven Systems', unity of a suprapositive system).

174 Konrad Zweigert, 'Rechtsvergleichung, System und Dogmatik', in Festschrift für Eduard Bötticher (1969), 443, 448.

175 For criticism, see Ernst Kramer, 33 RabelsZ 10-12, against Esser and Rothoeft. Riles, 40 Harvard International $L J 244 \mathrm{f}$, posits that the postmodern attack against modernist comparative law parallels the modernist attack against earlier comparative law.

176 Adaptation, Goal attainment, Integration, Latency. 
Comparative lawyers may first respond that they do what functionalist lawyers like Philipp Heck did: if rules and systems cannot be discarded altogether, they should at least be improved. For example, comparison reveals that ownership is transferred by mere consent in some legal systems, while others require the passing of possession, but the answers to specific fact situations are remarkably similar. These results can be formalized in three easy rules: Between transferor and transferee ownership passes through mere consent; with regard to third parties ownership passes through transfer of possession; third parties with notice must accept the transfer of ownership between transferor and transferee under the first rule. ${ }^{177}$ The ensuing system is still doctrinal and thus open to external criticism, but at least it describes the state of the different legal systems better than their own rules.

Of course this leaves the more fundamental criticism against any kind of systembuilding at large. This criticism cannot be avoided, because system-building is inherently linked with equivalence functionalism. ${ }^{178}$ Three kinds of relations are indispensable for functional comparison: the similarity relation between the problems in different societies, the functional relation between each individual problem and the legal institution with which a given legal system responds to it, and the equivalence relation between the institutions in different legal systems. The question phrased by functionalist comparison therefore already entails a system; Zweigert's system-building only formalizes it. It would be a mistake to consider this functional system as somehow more real than the doctrinal legal systems from which it is derived, if only because its formulation is necessarily formal, too. The system created by equivalence functionalism is a construction, and as such it is open to criticism like any other system. But it may be a better, more appropriate system than others, it may provide new angles on the legal systems we compare, and it may thereby help us both understand and critique those systems.

\section{The Evaluative Function: Determining the Better Law}

While the construction of a system is thus an implicitly normative-critical project, functionalist comparative law sometimes asserts an explicitly normative function: Functionality should serve as a yardstick to determine the 'better law'. This step from facts to norms is always problematic in comparative law. Saleilles proposed to look to the majority solution of legal orders to find a 'droit idéal relatif', 179 but

\footnotetext{
177 Ralf Michaels, Sachzuordnung durch Kaufvertrag (2002), especially 188 ff; cf already Fr. Vinding Kruse, 'What Does "Transfer of Property" Mean with Regard to Chattels? A Study in Comparative Law', (1958) 7 AJCL 500-15; Rodolfo Sacco, 'Diversity and Uniformity in the Law', (2001) 49 AJCL 171, $183 \mathrm{f}$.

178 Luhmann, 'Funktionale Methode und Systemtheorie' (n 100).

179 Saleilles (n 45); idem, 'École historique et droit naturel', (1902) 1 Revue trimestrielle de droit civil 80, 101, 106, 109 ff; Zweigert, 15 RabelsZ 19-21.
} 
why should majority suggest superiority? The Common Core projects look to commonalities among all legal orders, but even the fact of commonality (to the extent it exists) does not have intrinsic normative force. ${ }^{180}$ Indeed, functional comparatists often hesitate to move to such normative conclusions. Rabel, for example, argued that evaluation was not strictly an element of comparative law. ${ }^{181}$ The neo-Kantians' concept of ideal law is independent of existing legal orders. ${ }^{182}$ Both approaches thus face the same problem from different sides. The sociologist cannot deduce an 'ought' from an 'is'; comparative material gives no guidelines; even commonality has no independent normative force. The idealist philosopher can develop his ideal law in the abstract; but it is not clear how the knowledge of the different legal orders can help him or why that knowledge is even relevant.

Zweigert himself was aware that the empirical material collected by the comparatist did not have legal authority ${ }^{183}$ and that the comparative lawyer, in order to determine the better law, 'must operate with assumptions which ... would rightly be derided by the sociologist of law as simple working hypotheses'. ${ }^{184}$ But he thought that, whenever functionalist comparative law studies find similarity in result among different legal orders, all that needs to be evaluated is the better doctrinal formulation, and this is a task that the jurist is both able and entitled to do. ${ }^{185}$ Others seem more ambitious. ${ }^{186}$

The unease is justified: equivalence functionalism provides surprisingly limited tools for evaluation. ${ }^{187}$ The specific function itself cannot serve as a yardstick, for functionally equivalent institutions are by definition of equal value with respect to that function-equivalence means, literally, of equal value. Once a specific function has been used to determine relative similarity, the same function cannot determine superiority, for this would require a relative difference. It is impossible first to isolate the function of a legal institution from its doctrinal formulation and to measure this remaining functional element against some ideal function, for no such ideal function exists beyond the mundane reality of the legal order. In this strict sense, better-law theory is not compatible with functionalist comparative law.

180 Hill, 9 Oxford Journal of Legal Studies 103; J. P. Verheul, 'Così fan tutte', in Comparability and Evaluation: Essays on Comparative Law, Private International Law and International Commercial Arbitration in Honour of Kokkini-Iatridou (1994), 143-9.

181 Rabel, 13 Rheinische Zeitschrift für Zivil- und Prozeßrecht 280 (but see $286 \mathrm{ff}$ ).

182 Radbruch, 'Über die Methode' (n 20); Salomon (n 21), 30 ff; Blomeyer (n 143), 2.

183 Zweigert, 15 RabelsZ 14 f; idem, 'Die kritische Wertung in der Rechtsvergleichung', in Law and Trade: Recht und Internationaler Handel. Festschrift für Clive Schmitthoff (1973), 403, 405.

184 Zweigert and Kötz (n 2), 11 f; cf 47.

185 Zweigert, 'Kritische Wertung' (n 183), 408 f; for a more explicit is/ought cross-over, see idem, 15 Rabels $Z$ 20.

186 Rheinstein, 5 University of Chicago $L R, 617 \mathrm{f:} \mathrm{'[E]very} \mathrm{rule} \mathrm{and} \mathrm{institution} \mathrm{has} \mathrm{to} \mathrm{justify} \mathrm{its} \mathrm{exist-}$ ence under two inquiries: First: What function does it serve in present society? Second: Does it serve this function well or would another rule serve it better? It is obvious that the second question cannot be answered except upon the basis of a comparison with other legal systems' (internal footnote omitted).

187 cf Niklas Luhmann, Zweckbegriff und Systemrationalität (1968), 120. 
This may explain why so many comparative studies list similarities and differences and then run out of criteria to determine which of the laws is better.

If the yardstick must therefore lie outside the specific function under scrutiny, it can be found either in the costs of an institution, or in its functionality or dysfunctionality regarding other problems. This, however, makes a comprehensive evaluation almost impossibly complex. Take, for example, the different responses to car accidents of the New Zealand insurance system and the English tort law system. Arguably, New Zealand's law is functionally superior to English law regarding the function of compensation, because its transaction costs are lower. English law in turn is arguably superior with regard to the function of deterrence, because it creates better incentives for careful driving. Now, equivalence functionalism suggests that New Zealand meets the latter function of deterrence with other institutionscriminal liability, for example-so we have to account for this in our evaluation, too. But criminal law is costly and perhaps dysfunctional in so far as it clutters courthouses, so we must also take the costs of court procedures into account, and so forth. Micro-comparison regarding individual functions turns into macro-comparison between whole legal systems.

This example illustrates the crux of equivalence functionalism: its advantages in achieving comparability turn into disadvantages for evaluation. The focus on functional equivalence instead of similarity or difference is a deliberate way of mastering complexity without reducing specificity: institutions are made comparable precisely by reducing them to one function. To evaluate these institutions, however, it is not enough to focus only on this one function, because institutions are multifunctional; yet the focus on all other functions and dysfunctions reintroduces complexity.

This does not make an evaluation of the results of functionalist comparison impossible, but it shows its limits. ${ }^{188}$ First, the criteria of evaluation must be different from the criteria of comparability. Ultimately, evaluation remains a policy decision, a practical judgment, under conditions of partial uncertainty. The functional method can show alternatives and provide some information and thereby greatly improve this policy decision, but it cannot substitute for it. Second, any evaluation of functionally equivalent solutions is valid only with regard to the function scrutinized in the comparative inquiry-one law, one institution is not better than the other tout court. At best it may be better regarding a certain function. Thus, equivalence functionalism makes comparability possible, but simultaneously suggests restraint in evaluating results.

A good example for the strengths and limits of functionalism for evaluation is the House of Lords decision in White $v$ Jones. ${ }^{189}$ The question was whether a solicitor who had negligently failed to finalize a will was responsible to the intended beneficiaries. The Court starts by assessing several functions of liability: Tort-feasors

188 Prudent functionalists admit this much, eg Rheinstein, 5 University of Chicago LR 618.

189 [1995] 2 AC 207. 
should not go 'scot-free', solicitors should maintain a high standard, legacies play an important role in society, etc. Then the Court compares various functionally equivalent foreign doctrinal constructions that would support the solicitor's liability as to their adequacy within English law. However, while these foreign solutions are comparable because they are responses to the same problem (functionalism), the second step, assessing whether these solutions could be adopted in English law, is a matter of doctrinal fit within English law. Functionalism could play no role in this.

\section{The Universalizing Function: Unifying Law}

Evaluation is closely linked to another function connected with the functional method since its early days: to be a tool for the unification of law. Functionalist comparatists advocate their method as ideal for this purpose, whether regionally (eg in Europe), or worldwide. Their argument rests on functionalism's ability to identify similarities among seemingly different laws; it should enable lawmakers to write an optimal uniform law that overcomes and transcends the doctrinal peculiarities of local legal systems. Once the functional similarities of different laws are realized, the argument goes, it becomes easier to unify them on the basis of these similarities.

Two problems with this argument have been treated above: the functional method alone cannot reveal the best legal system (Section III.5), and as an antidoctrinal method it is not well equipped for the formulation of legal rules that must be doctrinal (Section III.4). Lawmakers cannot ignore lawyers' actual experiences with legal doctrine and the creation of systems if they want to create a new doctrine and a new system. ${ }^{190}$ Functionalist comparative law works well for critiquing doctrine, far less well for its establishment.

Yet there is an additional, slightly less obvious reason why functionalist comparative law is a particularly bad tool for the unification of law. A teleological version of functionalism may well contain a preference for convergence, some elements of which appear in the work of both Rabel and Zweigert. Equivalence functionalism, on the other hand, provides arguments against unification. If different legal systems are already similar regarding individual functions, as the functional method shows, then the benefits from unification lie only in formal improvements ${ }^{191}$ and may well be outweighed by the costs. ${ }^{192}$ First, it is often

190 Christian Baldus, 'Historische Rechtsvergleichung im zusammenwachsenden Europa: Funktionelle Grenzen der funktionellen Methode?', (2003/2004) 1 Zeitschrift für Gemeinschaftsprivatrecht 225; cf Jansen (n 153), 72 ff.

191 See eg Ugo Mattei, 'A Transaction Cost Approach to the European Code', (1997) ERPL 537, 540.

192 See eg Hein Kötz, 'Rechtsvereinheitlichung: Nutzen, Kosten, Methoden, Ziele', (1986) 50 RabelsZ 1-17; Christian Kirchner, 'A "European Civil Code": Potential, Conceptual, and Methodological Implications', (1998) 31 University of California Davis LR 671, $686 \mathrm{ff}$. 
inefficient for lawyers to learn new formal rules if these fulfil the same functions as the old ones; this is one important reason for practitioners' continuing lack of interest in the UN Sales Convention and for the reserved reactions of European business to proposals for a unified European contract law. ${ }^{192 \mathrm{a}}$ Second, the functional method assumes that each legal institution performs a variety of functions within its legal system and that there is a sensitive interaction among the various institutions in each system that accounts for intersystemic differences. Unification of individual areas of the law is then likely to unsettle this balance. This can be observed in the difficult coordination between the United Nations Sales Convention (CISG) and national legal systems. ${ }^{193}$ The functional method with its emphasis on functional equivalence shows why unification may be easier than one might think, but also why it is less important.

Of course, the last argument of interactions within a system can also provide an argument in favour of unification. That different legal systems respond to similar problems with different needs leads to problems in choice of law if actors, willingly or unwillingly, pick and choose solutions from different legal orders that do not combine into a whole. For example, one legal system may protect surviving spouses through the law of succession, the other through family law; one legal system protects poor parties through the law of damages, the other through the law of procedure. This can lead to inconsistencies if, under a choice of law analysis, different laws are applicable for different areas. Most of these problems, however, can be countered through a functionalist approach to choice of law. ${ }^{194}$

It becomes evident, somewhat surprisingly, that the functional method is not only a bad tool for legal unification, but even provides powerful arguments for maintaining differences. Indeed, modern law makers often prefer functional equivalence to unification. For example, in European Union law, directives must be implemented not in their doctrinal structure but only with regard to their results; the implementing laws in the member states are not similar but functionally equivalent. Similarly, the principle of mutual recognition in European Union law requires not similarity, but equivalence-presumably functional equivalence. ${ }^{195}$ The OECD Convention on Corruption requires its member states to use not

\footnotetext{
$12^{\mathrm{a}}$ But see now Stefan Vogenauer and Stephen Weatherill, 'The European Community's Competence to pursue the Harmonisation of Contract Law - An Empirical contribution to the Debate', in Vogenaur and Weatherill (eds), The Harmonisation of European Contract Law (2006), 105, $119 \mathrm{ff}$.

${ }^{193}$ For use of functionalist comparative law here see Franco Ferrari, 'The Interaction between the United Nations Convention on Contracts for the International Sale of Goods and Domestic Remedies (Rescission for Mistake and Remedies in Torts)' (forthcoming 2007) 71 RabelsZ Issue 1.

194 Below, pp $378 \mathrm{f}$.

$195 \mathrm{cf}$ the examples of education degrees and data protection in Scheiwe, 83 Kritische Vierteljahresschrift für Gesetzgebung und Rechtswissenschaft $31 \mathrm{f}$.
} 
similar, but functionally equivalent measures against corruption. ${ }^{196}$ So does international trade law: In the famous semi-conductors case, Europeans complained that through monitoring Japanese corporations, the Japanese government was effectively preventing those companies from exporting below certain companyspecific costs. Japan countered that monitoring measures were not restrictions. However, a GATT panel made clear that the formal character of a governmental measure was irrelevant as long as it operated in a manner equivalent to mandatory restrictions. ${ }^{197}$ In the Japanese legal culture, even formally non-binding measures imposed by the government were considered and treated as binding. They were, in other words, functionally equivalent.

\section{The Critical Function: Critique of Legal Orders}

This leaves the last proclaimed function of functional analysis, its critical function in various ways: tolerance of foreign law, critique of foreign law, critique of our own law, and critique of law in general. Functionalism does not fare equally well for all of these.

Functionalist comparative law can overcome a home bias against foreign law. ${ }^{198}$ This shows particularly well in the conflict of laws, in which the question of accepting foreign law gains practical relevance, and functionalist comparison is often applied. ${ }^{199}$ The most famous example for functionalism in the conflict of laws is Rabel's proposal to use functional comparison for the purpose of characterization. ${ }^{200}$ Similarly, substitution and adaptation, the (somewhat idiosyncratic) methods of aligning different legal orders, require functional comparison. But the most important use of functionalist comparisons and functional equivalence concerns the question whether application of foreign law violates the forum's public policy. The German Bundesgerichtshof, holding that a foreign judgment on punitive

\footnotetext{
196 Gemma Aiolfi and Mark Pieth, 'How to Make a Convention Work: the Organisation for Economic Co-operation and Development Recommendation and Convention on Bribery as an Example of a New Horizon in International Law', in Cyrille Fijnaut and Leo Huberts (eds), Corruption, Integrity and Law Enforcement (2002), 349, 351-3; Mireille Delmas-Marty, Le relatif et l'universel (2004), 253-7.

197 Japan: Trade in Semi-conductors, Report of the Panel adopted on 4 May 1988, L/6309, Basic Instruments and Selected Documents 35S/116, especially nn 109, 117.

198 Martijn W. Hesselink, The New European Legal Culture (2001) 51, 55.

199 For the usefulness of functionalist comparison for conflict of laws, see Arthur T. von Mehren, 'An Academic Tradition for Comparative Law?', (1971) 19 AJCL 624, 625.

200 Ernst Rabel, 'Das Problem der Qualifikation', (1931) 5 RabelsZ 241-88. Graziadei (n 6), 103 ff, even posits that the roots of functional comparative law are in problems of characterization. Yet while early texts on functionalism draw the connection frequently, Rabel himself pointed to his education in legal history as the source for his functional approach: Rabel, 'In der Schule' (n 149) 158 f; and see Reinhard Zimmermann, "In der Schule von Ludwig Mitteis": Ernst Rabels rechtshistorische Ursprünge’, (2001) 65 Rabels $Z_{1,35} \mathrm{f}$.
} 
damages did not automatically violate German public policy, relied on an extensive analysis of the various functions of punitive damages and its German functional equivalents. ${ }^{201}$ A Californian Court of Appeal relieved a French company of the requirement that it attain workers' compensation insurance from a Californian insurer, holding that the manifest function of the requirement-that employers should be adequately insured by a solvent company-could be attained by different means, in this case insurance with a French company. ${ }^{202}$ Western courts are now more willing than before to recognize Islamic divorce based on unilateral repudiation because it is functionally equivalent to divorce in Western democracies, which, though nominally consensual, can effectively be brought about against or without the will of one of the spouses. ${ }^{203}$ Between EU member states, community law restricts the application of mandatory norms of the forum law if the foreign law contains functionally equivalent norms. ${ }^{204} \mathrm{In}$ all these cases, the tolerance for foreign law is brought about by the recognition of functional equivalence.

At the same time, functionalist comparison can aid in critiquing foreign law, especially when a legal system insists on its cultural autonomy. For the sake of plurality and autonomy, critical strands in comparative law often invoke culture against functionalism. But culture is sometimes invented and sometimes undesirable. Distinguishing 'good' from 'bad' culture is difficult for an insider lacking a critical perspective, as well as for an outsider lacking sufficient insight. Functionalist comparative law can be helpful here in preparing the ground for critique, because it combines two important perspectives: awareness of culture on the one hand, and a perspective from outside on the other. By reconstructing legal culture in functional terms, functional comparative law helps preserve the culture's otherness while making it commensurable with our own law-we see the foreign law's functions and dysfunctions, both manifest and latent, and we know from comparison how else these effects can be brought about. The method does not provide us with the tools to evaluate the foreign law. But without the groundwork laid by functionalist comparisons, such evaluation is hard to formulate.

On the other hand, functionalist comparative law helps less in critiquing one's own law. The reason is again functional equivalence: Because we cannot say easily whether a foreign law is better than our own, recognizing different solutions abroad does not show us deficiencies at home. Functionalist comparison can open

\footnotetext{
201 BGH (4 June 1992), BGHZ 118, 312; English translation in (1993) 32 International Legal Materials 1327.

202 Tucci v Club Mediterranee, SA, 89 Cal App. 4th 180, $192 \mathrm{f}$.

203 See eg Mathias Rohe, 'The Application of Islamic Family Law in German Courts and its Compatibility with German Public Policy', in Jürgen Basedow and Nadjma Yassari (eds), Iranian Family and Succession Laws and their Application in German Courts (2004), 19, 28 ff. But see Cass Civ (17 February 2004), D 2004, 825.

204 Hélène Gaudemet-Tallon, 'De nouvelles fonctions pour l'équivalence en droit international privé?', in Le droit international privé: esprit et méthodes. Mélanges en l’honneur de Paul Lagarde (2005), $303,315 \mathrm{ff}$.
} 
our eyes to alternative solutions, but it cannot tell us whether those alternative solutions are better or not. Functionalism can provide us with a view of our own law from the outside, but whether what we thus see is deficient must be determined by other criteria. Functionalism can be critical of doctrinalism by revealing the contingency of any one doctrine, but it cannot show a way towards law without any doctrine, and it cannot itself provide such law.

Finally, functionalism is unhelpful in various respects in which critique may be desirable. First, functionalism does not help in evaluating functionality and purposes. ${ }^{205}$ Quite to the contrary, in showing that other societies pursue the same goals by different means, it may reinforce our conviction that certain purposes are somehow necessary. Second, functionalism does not help us much in a fundamental critique of law. Functionalism may show how other societies fulfil certain needs with other institutions than law, but it cannot provide alternatives to the functionalist thinking inherent to our thinking about law. Third, with its emphasis on understanding the status quo and on apolitical analysis, functionalist comparative law is of little use for political governance projects. ${ }^{206}$ Fourth, because functionalist comparative law presumes separate societies and separate legal systems as objects of comparison, it is unable to conceptualize the way in which these systems and societies are interdependent and overlap, a growing problem under conditions of globalization. Fifth, functionalist comparison is unable to account for tensions within legal systems, at least so long as it focuses on the relations between whole legal systems rather than on legal subsystems. All of these are real shortcomings, not only of the functional method in comparative law, but of traditional comparative law at large, and to this extent critiques of the functional method that are really aimed at mainstream comparative law are justified. But it remains doubtful whether any method of comparative law can fare better here.

\section{Conclusion}

Section III has rendered some surprising results. Generally, one assumes that the strength of the functional method lies in its emphasis on similarities, its aspirations towards the evaluation and unification of law. This is the main reason why its

205 Hill, 9 Oxford Journal of Legal Studies $106 \mathrm{f}$.

206 David Kennedy, 'New Approaches to Comparative Law: Comparativism and International Governance', 1997 Utah LR 545, $588 \mathrm{ff}$; but see, for a promising proposal, Richard Buxbaum, 'Die Rechtsvergleichung zwischer nationalem staat und internationaler Wirtschaft', (1996) 6o RabelsZ 201, $211 \mathrm{ff}$. 
supporters since Rabel have considered it such a powerful tool, and why opponents have felt the need to combat it so fiercely. Yet the discussion has revealed that the functional method emphasizes differences within similarity; it does not provide criteria for evaluation; and it supplies powerful arguments against unification. Further, one generally assumes that the functional method does not account sufficiently for culture and is reductionist. But as the analysis demonstrates, the functional method not only requires us to look at culture, but it enables us to formulate general laws without having to abstract the specificities.

These misunderstandings about the utility of the functional method arise because comparatists unknowingly use different concepts of function, as demonstrated in Section II. Because the relation between these different concepts within the method was unclear, some of the hopes placed in the functional method were unrealistic. Comparatists' shift from a sociologically inspired to a legally inspired concept of function within the functional method occurs quite precisely when they move from description to systematizing and evaluation. A method reconstructed plainly on the basis of functional equivalence as the most robust of the concepts and following a constructive epistemology can make fewer claims in these last four areas; in fact, it can suggest reasons for caution and restraint. At the same time, such a method is less open to some of the criticism levelled against the functional method as an explanatory tool.

Other disciplines have discarded functionalism only after utilizing its insights. Functionalist comparative law has not yet made sufficient use of the benefits of functionalism. This study can only hint at the possibilities, but its findings suggest that a more methodologically aware functionalism will provide us with better insights into the functioning of law. In addition, functionalism in comparative law may well be immune to some of the criticism voiced against functionalism in the social sciences. After all, law is a normative discipline for which teleology may be useful or even necessary. Of course, this requires the construction of a more robust functional method. This chapter proposes to base such a method on equivalence functionalism and on an epistemology of constructive functionalism. Whether such a method can hold its own-against the uncritical version of functionalism on the one hand, and against the alternatives to functionalism on the otherremains to be seen. But the attempt seems well worth the effort.

\section{B I B LI O G R A P HY}

Émile Durkheim, Les règles de la méthode sociologique (1895, 5th edn 1988)

Ernst Cassirer, Substanzbegriff und Funktionsbegriff (1910)

Ernst Rabel, 'Aufgabe und Notwendigkeit der Rechtsvergleichung', (1924) 13 Rheinische Zeitschrift für Zivil- und Prozeßrecht 279-301; reprinted in Hans G. Leser (ed), Ernst Rabel, Gesammelte Aufsätze (vol III, 1967), 1-21 
Max Rheinstein, 'Teaching Comparative Law', (1937-8) 5 University of Chicago LR 615-24 Josef Esser, 'Universale Prinzipien als Basis der Funktionsvergleichung von Privatrechtsinstituten', chapter 10 of Grundsatz und Norm in der richterlichen Fortbildung des Privatrechts (1956), 346-81

Niklas Luhmann, 'Funktion und Kausalität', (1962) 14 Kölner Zeitschrift für Soziologie und Sozialpsychologie 617-44; reprinted in idem, Soziologische Aufklärung (vol I, 7th edn, 2005), 1-38

Robert K. Merton, 'Manifest and Latent Functions', in idem, Social Theory and Social Culture (enlarged edn, 1968), 73-138

Niklas Luhmann, 'Funktionale Methode und juristische Entscheidung', (1969) 94 Archiv für öffentliches Recht 1-31; reprinted in idem, Ausdifferenzierung des Rechts (paperback edn, 1999), 273-307

Konrad Zweigert and Hein Kötz, Einführung in die Rechtsvergleichung (1st edn, 1969-71, 3rd edn, 1996; English translation under the title An Introduction to Comparative Law by Tony Weir, 3rd edn, 1998)

Volkmar Gessner, 'Soziologische Überlegungen $\mathrm{zu}$ einer Theorie der angewandten Rechtsvergleichung', (1972) 36 RabelsZ 229-60

Robert W. Gordon, 'Critical Legal Histories', (1984) 36 Stanford LR 57-126

Günter Frankenberg, 'Critical Comparisons: Re-thinking Comparative Law', (1985) 26 Harvard International LJ 412-55

Kirsten Scheiwe, 'Was ist ein funktionales Äquivalent in der Rechtsvergleichung? Eine Diskussion an Hand von Beispielen aus dem Familien- und Sozialrecht', (2000) 83 Kritische Vierteljahresschrift für Gesetzgebung und Rechtswissenschaft 30-51

Jaakko Husa, 'Farewell to Functionalism or Methodological Tolerance?', (2003) 67 RabelsZ 419-47

Michele Graziadei, 'The Functionalist Heritage', in Pierre Legrand and Roderick Munday (eds), Comparative Legal Studies: Traditions and Transitions (2003), 100-27 